\title{
From Stagnation to Sustained Growth: The Role of Female Empowerment
}

\author{
Claude Diebolt and Faustine PerRin*
}

[Draft - please do not quote or cite without permission]

This paper explores the role of gender equality over long-run economic and demographic development path of industrialized countries. It accounts for changes in fertility, technology and income per capita in the transition from stagnation to sustained growth. Our unified cliometric growth model of female empowerment suggests that changes in gender relations, triggered by endogenous skill-biased technological progress, induce women to invest in skilled education and engage a process of human capital accumulation. In parallel, a higher time spent by women in education increases the opportunity cost of having children and reduces fertility. This positive feedback loop generates both a demographic and an economic transition.

Keywords: Cliometrics, Economic Growth, Gender, Fertility, Human Capital JEL Classification: J1, N3, O4

\footnotetext{
* Diebolt: Department of Economics, BETA/CNRS (UMR 7522), University of Strasbourg, 61 avenue de la Forêt Noire, France (e-mail: cdiebolt@unistra.fr); Perrin: Department of Economics, BETA/CNRS (UMR 7522), University of Strasbourg, 61 avenue de la Forêt Noire, France (e-mail: faustine.perrin@unistra.fr). Acknowledgments: participants at the Tübingen Workshop on Human Capital in Economic History 2010, the 2011 ASSA Meetings - Cliometric Society in Denver, the $9^{\text {th }}$ EHES Conference in Dublin, the $8^{\text {th }}$ BETA Workshop in Strasbourg, and the 2012 ASSA Meetings American Economic Association in San Diego. Any and all errors and omissions are our own. Financial support from the University of Strasbourg Institute for Advanced Study (USIAS) is gratefully acknowledged.
} 


\section{Contents}

1. The Stylized Facts - Gender, Fertility and Growth ............................................ 8

$1.1 \quad$ Gender Equality, Fertility and Development ....................................................... 8

1.1.1 Gender Equality and Fertility ...................................................................... 8

1.1.2 Gender Equality and Human Development ....................................................... 10

1.1.3 Gender Equality and Economic Development................................................... 11

1.2 Demographic and Economic Long-run Trends.......................................................... 12

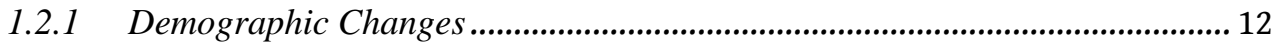

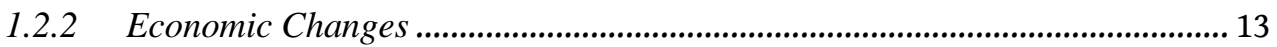

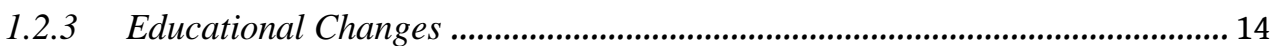

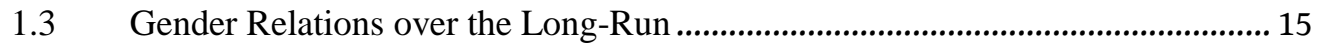

1.3.1 The Traditional Role of Women (From Complementarity...)........................... 16

1.3.2 The Emergence of New Economic Role of Women (...Toward...) ................... 16

1.3.3 The "Quiet Revolution” (...Gender Equality) ..................................................... 18

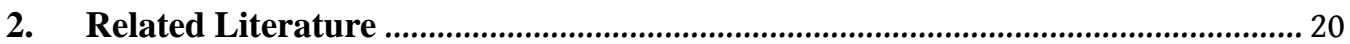

2.1 Theoretical Foundations of the Development Process ........................................ 20

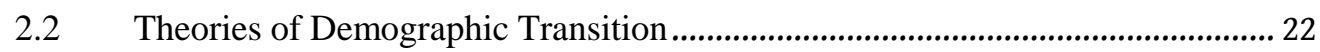

2.3 The Unified Growth Theory ................................................................................. 23

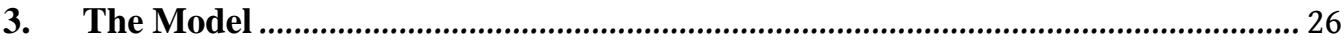

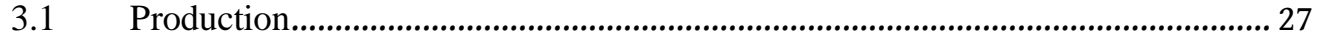

3.1.1 Production of Final Output ............................................................................ 27

3.1.2 The Production of Human Capital .................................................................. 27

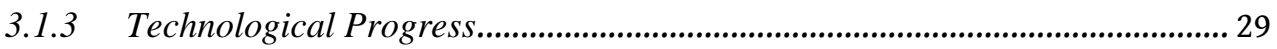

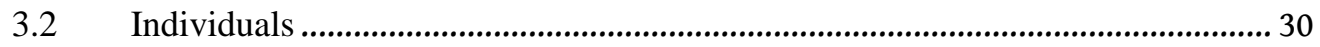

3.2.1 Preferences and Budget Constraint............................................................... 30

3.2.2 The Household Choice Problem .......................................................................... 32

3.2.3 Choice of Human Capital and Fertility............................................................ 34

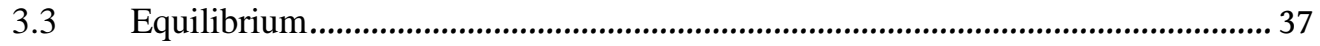

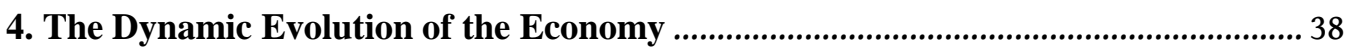

4.1 Dynamic Evolution of the Key Variables ......................................................... 38

4.1.1 The Fraction of Skilled Individuals .................................................................... 38 


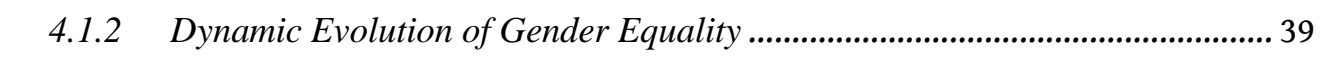

4.1.3 Process of Technological Process .................................................................. 39

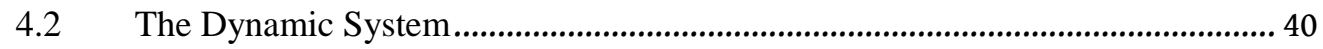

4.3 The Global Dynamics of Development .................................................................. 41

4.3.1 Non-Developed Economy ................................................................................. 41

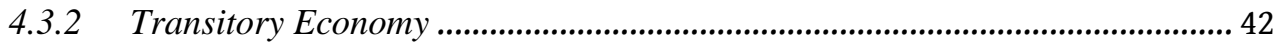

4.3.3 Developed Economy ....................................................................................... 43

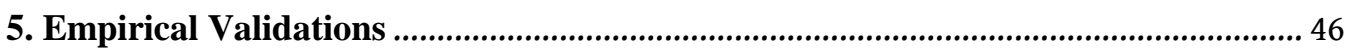

5.1 A County-level Database for France in 1851 .................................................... 46

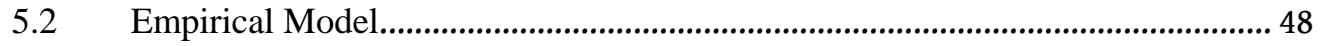

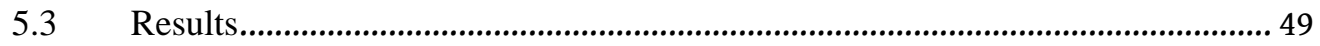

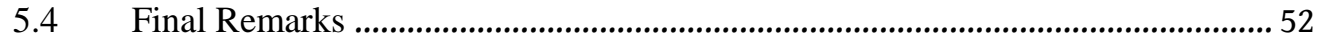

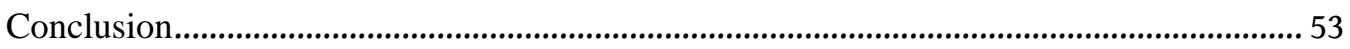

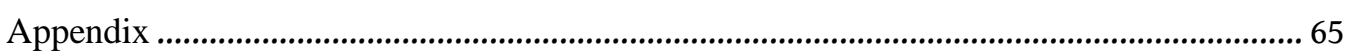


That cliometrics is an indispensable tool in the study of long run economic growth is no longer a very controversial statement. It is now generally agreed that economic theory, combined with historical, statistical and mathematical methods are necessary at the theoretical level, to formulate problems precisely, to draw conclusions from postulates and to gain insight into workings of complicated processes. At the applied level, it allows to measure variables, to estimates parameters and to organise the elaborate calculations involved in reaching empirical results. This article is an illustration of our belief in this principle. It explores the role of gender equality over long-run economic and demographic development path of industrialized countries.

The relationship between gender equality and long-run economic growth has received little attention from theorists so far. Understanding gender roles is difficult in that it requires a global understanding of family organization and its interaction with the marketplace. However, we strongly believe that changes in gender roles have played a key role in the economic development of modern societies. Insights from economics suggest the role of women to be a strategic variable in economic development, through its effects on demographic behavior as well as on human-capital formation in the next generation.

During the past two centuries, Western world witnessed dramatic economic, demographic and cultural upheavals. This period marks a turning point in historical economic and demographic trends. Western countries experienced similar patterns of economic and demographic transition, despite some variations in terms and timing and speed of changes (Galor, 2012). Before the Industrial Revolution, all societies were characterized by a very long period of stagnation in per capita income with high fertility rates. Since this fateful period, Western countries observed a complete reversal with high sustained income per capita and low fertility (Becker et al., 2012, Klemp, 2012). In parallel to economic and demographic transitions, we note profound changes in the structure of the population: formal education became accessible to a vast majority of the population while drastic changes occurred in gender relations.

Observed empirical regularities raise numerous questions about the potential interaction between female empowerment, demographic transition and economic development; and about its role in the transition from the epoch of Malthusian stagnation to the Modern Growth Regime (Galor and Moav, 2002). Therefore, what can explain the dramatic reversal of the relationship between output growth and population? What are the underlying behavioral forces behind the 
demographic transition? What are the endogenous interactions between education and fertility that result in the transition phase? Could female empowerment account for the observed take-off from stagnation to sustained growth in Western countries?

The theories which aim to explain development and economic growth have, for a long time, found their inspiration in Malthusian and neoclassical conceptions. Without technological progress, Malthus' theory suggests that the size of the population self-balances either under biological constraint or individuals' rationality. On the other hand, Solow's model (1956) deals with the demographic growth as an exogenous variable, independent of wages, incomes and prices. Without technological progress, the income per capita converges towards a stable steady-state but independently of the population size. These two theoretical axes do not address the proper effects of family behavior on the macroeconomic environment (and inversely). Initiated by Becker (1960, 1965), Leibenstein (1957) and Mincer (1962), the "new home economics" extends the domain of microeconomic analysis to a wide range of behavior and human interaction, such as demographic behavior, investments in human capital, intergenerational transfers and so on (including the distribution of work and allocation of time in the family). A decade later, Nerlove (1970), Razin and Ben-Zion (1975) or Srinivasan (1988) link demographic behaviors to macroeconomic evolutions in order to analyze their implications on the general equilibrium ${ }^{1}$. Inspirited by these papers and by the endogenous growth models of Romer $(1986,1990)$ and Lucas (1988), growth models with explicit microeconomic foundations of family have then progressively been developed (Barro and Becker, 1989; Becker, Murphy and Tamura, 1990, Ehrlich and Lui, 1991; Galor and Weil, 1996; Dahan and Tsiddon, 1998; Iyigun, 2000). The progress of endogenous neoclassical growth models may provide plausible explanations of the modern experience of economic growth in developed economies. Nonetheless, they do not provide a global understanding of the development process as a whole (mysteries persist about some of the most fundamental features of the process of development). This led growth theorists, such as Galor, to advance the idea of a theory that could captures in a single framework the transition from Malthusian stagnation to sustained economic growth, as well as the associated phenomenon of great divergence and

\footnotetext{
1 Within the framework of neoclassical growth model with endogenous fertility, the authors attempt to determine the optimal population growth rate.
} 
demographic transition. Galor and Weil $(2000)^{2}$ emphasize the existence of three stages within the development process through the evolution of the relationship between the level of income per capita and the population growth rate. During the Malthusian Era (stagnation), population growth was positively affected by the level of income per capita. The absence of significant changes in the level of technology trapped the income per capita around a subsistence level and population size remained relatively stable. The Post-Malthusian Regime (take-off) is characterized by a significant increase in the output growth, driven by technological progress, and by an unprecedented increase in population growth. Finally, the Modern Growth Regime shows a reversal of the relationship between income per capita and population growth which signed the transition toward a state of sustained economic growth. Common to most unified models is the rise in the rate of technological progress (through the emergence of new technologies) during the process of industrialization which increases the demand for human capital and induces parents to invest more in the education of their offspring. Investing in education increases the opportunity cost of having children and implies for parents to choose between number and education of children (the child quantity-quality trade-off ${ }^{3}$ ), what ultimately triggers to economic and demographic transition.

This paper contributes to this literature on unified growth theory by bringing to light new determinants of the long transition process. Our model incorporates novel and additional mechanisms consistent with observed stylized facts, emphasizing the importance of the role played by women in the development process. Rare are growth models that differentiate the role of men and women in their analysis, considering rather the effect of household decisions on fertility. We choose here to tackle the issue of the development process by a renewed gender approach. The main concern of the study is precisely to show to what extent and through which mechanisms gender equality affects decisions taken by members of the household and acts on long run economic development. We examine mechanisms that are likely to have played an important role in the sequence of events leading to the transition from high birth and death rates to low birth and

\footnotetext{
2 The seminal work of Galor and Weil was quickly followed by new contributions for example, Jones (2001), Lucas (2002), Hansen and Prescott (2002), Galor and Moav (2002), Doepke (2004), Galor (2005), Cervellati and Sunde (2005), Strulik and Weisdorf (2008).

3 Becker (1960) was the first to introduce the distinction between child quantity and child quality.
} 
death rates as countries developed from a pre-industrial to an industrialized economic system.

We develop a unified cliometric growth model that captures the interplay between fertility, technology and income per capita in the transition from stagnation to sustained growth. The theory suggests that female empowerment has been at the origin of the demographic transition and engaged the take-off to Modern economic growth. In line with empirical evidence, the theory characterizes the conditions under which the process of human capital accumulation initiated. Changes in the shares of population acquiring skilled human capital have substantial effects on fertility patterns and affect individuals' living conditions.

In particular, we consider a two-sex overlapping-generations framework with two types of human capital and integrating aspects of gender relations/equality. Households' members receive utility from their own consumption and from the potential lifetime income of their children. Therefore, they decide about the amount of time to invest in the education process and the number of children they want to raise. We consider all childrearing completely done by women. The key state variables for individuals' decisions are the technological environment and the power-imbalance ratio between sexes. A rapid change in technological environment increases the return to skilled education and increases both boys' education and fertility through an income effect. Higher gender equality (triggered by the acceleration of the pace of technological progress) increases girls' education and reduces the total number of children, through a substitution effect. Furthermore, given the assumption that all childrearing is done by women, maternal endowment in human capital is recognized as being primordial in the educative development of children. Ultimately, higher gender equality changes the trade-off from quantity of children toward quality of children. The average level of fertility therefore depends on the skill composition of the population.

The different elements of our model lead to a positive feedback loop. At the dynamic level, the increase in gender equality and the rise in technological progress create higher opportunities for women to invest in skilled human capital. The negative correlation linking maternal investments in human capital and fertility encourages families to have fewer children but better educated ones. Dynamically, it affects the incentive for individuals to acquire skilled human capital. Human capital being a factor with increasing returns to scale, the 
reallocation of resources toward this factor sets the economy on a growing path dependency.

The paper is structured as follows. First, we present the stylized facts of the economic and demographic transition, and empirical regularities regarding changes in the educational structure of the population in France (section 1). Second, we present the theoretical background of the model (section 2). Then, we present the model (section 3). Next, we investigate the dynamic evolution of the economy (development process) (section 4). Finally, we document the long-run effect of investments in human capital on fertility changes from a gendered perspective (section 5).

\section{The Stylized Facts - Gender, Fertility and Growth}

In this section, we document the stylized facts and empirical regularities of demographic and economic transitions. Similar patterns emerge across countries despite some variations in terms and speed and timing (Galor, 2005). We briefly discuss current cross-country evidence of the relationship between gender equality and economic and demographic transition. Then, we describe French historical evidence of demographic and economic patterns, as well as regularities on skill composition of the population and on gender relations.

\subsection{Gender Equality, Fertility and Development}

We first observe the current correlations linking the Gender Gap Index (GGI) with the Total Fertility Rate (TFR), the Human Development Index (HDI) and the Gross Domestic Product per Capita (GDP per capita) for 114 countries in 2006.

\subsubsection{Gender Equality and Fertility}

Figure 1 shows the correlations linking the Gender Gap Index (GGI) with the Total Fertility Rate (TFR) in 2006. The GGI examines the gap between men and women in four fundamental categories: economic participation and opportunity, educational attainment, health and survival, and political empowerment. A GGI equal to 1 reflects perfect gender equality while 0 perfect inequality. The TFR of 
a population is the average number of children that women would have over their lifetime.

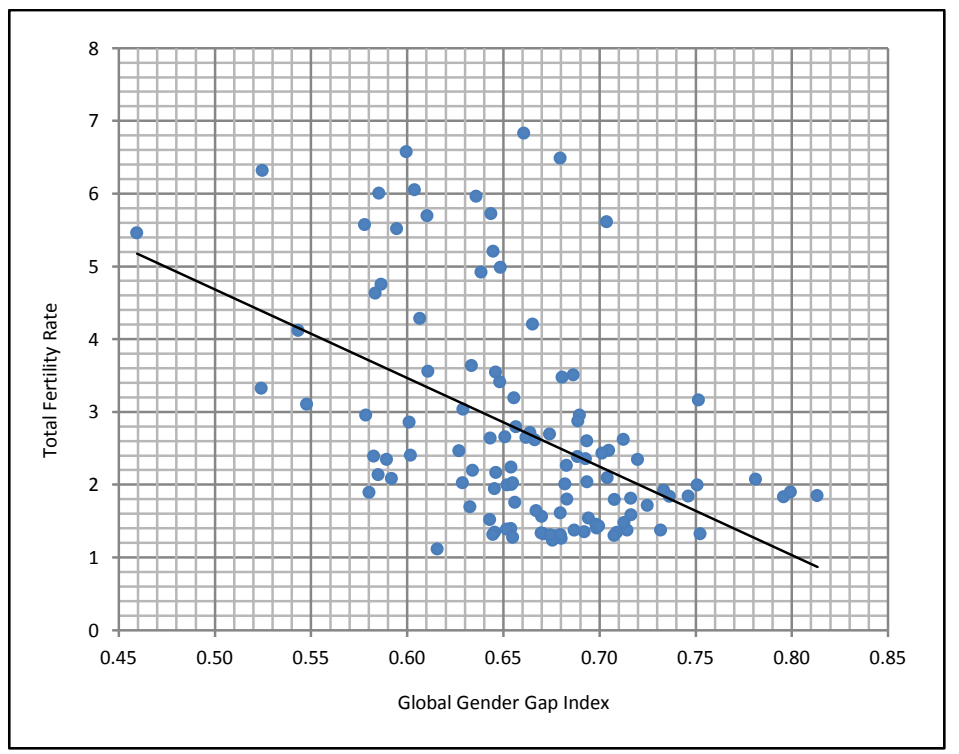

Figure 1. The Cross-Country Plot of Total Fertility RATE AND Gender GaP INDEX IN 2006

Notes: The data is for a set of 114 countries in 2006 (Global Gender Gap Report, Total Fertility Rate Report, World Bank) - details in Appendix.

The plot highlights the existence of a strongly negative correlation between the GGI and the TFR. Countries with a high level of equality between males and females have a low level of fertility. This is the case of countries such as Australia, Canada, Croatia, Denmark, Finland, Germany, Iceland, New Zealand, Norway, Sweden etc. (mainly OECD countries) - which are located in the high left part of the graph (number of children between 1.3 and 2 per women and gender gap between 0.7 and 0.85 ). Inversely, countries, in which the gender gap is high, experience high fertility level. This is the case of countries such as Angola, Ethiopia, Mali, Nigeria, Turkey, Yemen, Zambia etc. (Arabic countries, SubSaharan Africa, South and East Asia) - which are located in the high left part of the graph (number of children around 6 per women and gender gap between 0.46 and 0.64). 


\subsubsection{Gender Equality and Human Development}

In contrast with the previous illustration, gender equality (measured by the GGI) is highly positively correlated with human development (measured by the Human Development Index). The Human Development Index (HDI) is a comparative measure of life expectancy, literacy, education and standards of living. This index allows measuring the quality of life within a country.

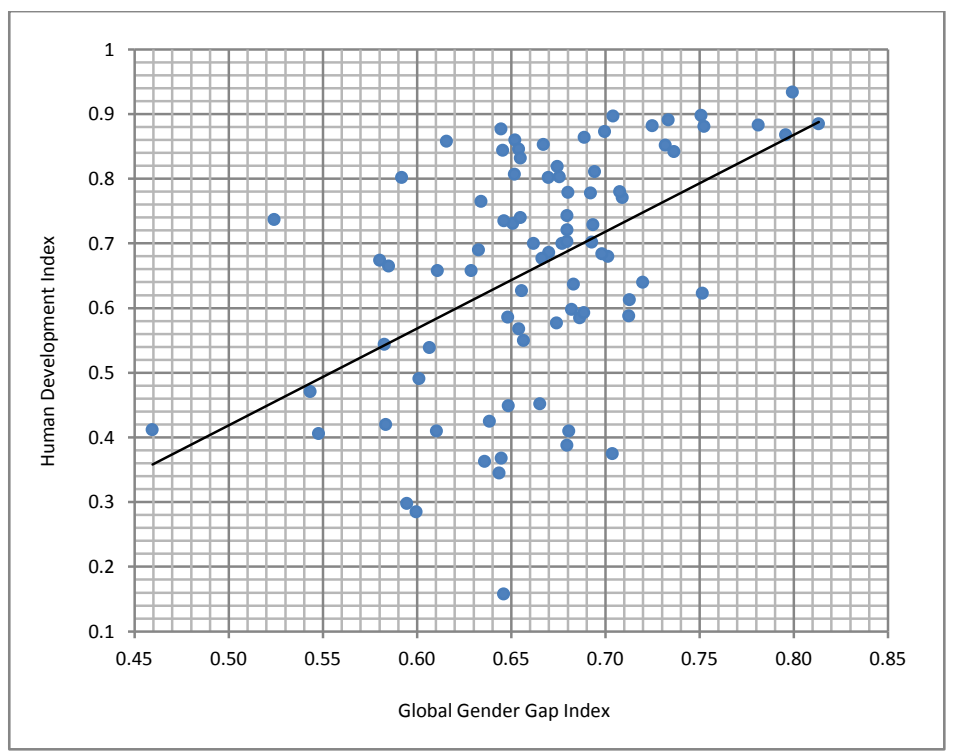

Figure 2. The CRoss-country Plot of Human DeVelopment IndeX AND Gender GaP INDEX IN 2006

Notes: The data is for a set of 114 countries in 2006 (Global Gender Gap Report, Global Human Development Report, World Bank) - details in Appendix.

The plot highlights the existence of a positive correlation between the GGI and the HDI. Countries with a high level of equality between males and females have a high level of human development, notably characterized by high education, high literacy and high life expectancy. This is the case of OECD countries such as Australia, Canada, Croatia, Denmark, Finland, Germany, Iceland, New Zealand, Norway, Sweden etc. - which are located in the high right part of the graph (index of human development around 0.8 and gender gap above 0.7). Inversely, countries, in which the gender gap is high, have a low development index. This is the case of countries such as Afghanistan, Angola, Ethiopia, Mali, Nigeria, 
Turkey, Yemen, Zambia, Zimbabwe etc. - which are located in the low left part of the graph (human development index below 0.6 and gender gap between 0.46 and 0.64 )

\subsubsection{Gender Equality and Economic Development}

Similarly to what has been shown in the previous sub-section, gender equality (measured by the GGI) is highly positively correlated with growth (measured by the log GDP per capita).

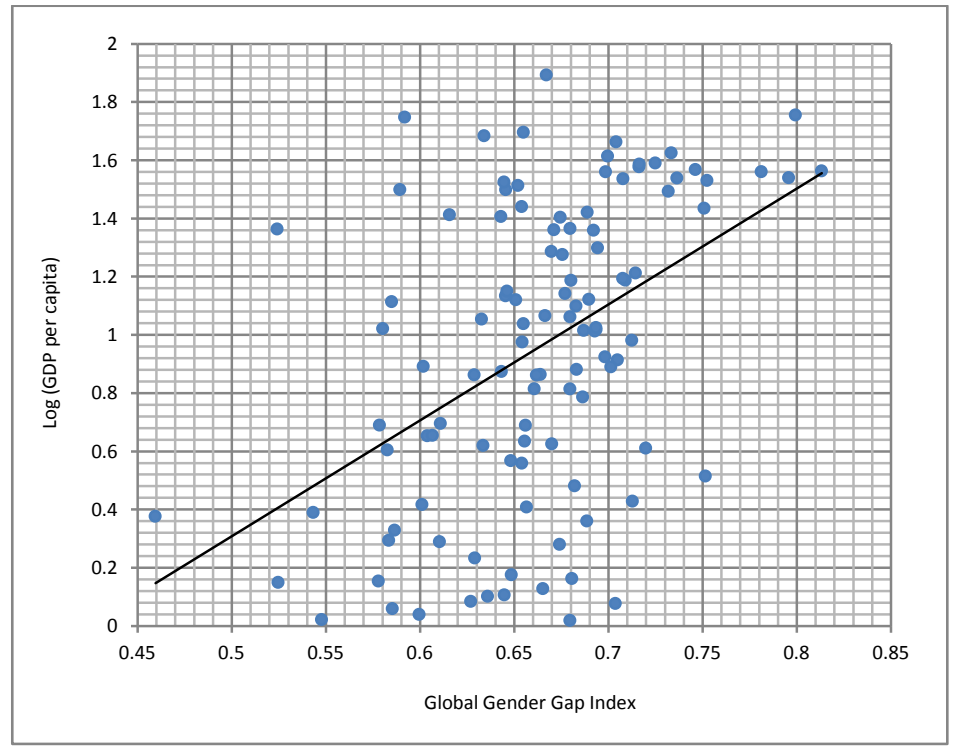

Figure 3. The Cross-Country Plot of PeR-CAPITA GDP AND Gender GAP INDEX IN 2006

Notes: The data is for a set of 114 countries in 2006 (Global Gender Gap Report, Per-Capita GDP Report, World Bank) - details in Appendix.

Countries with a high level of equality between males and females have a high level of GDP per capita. This is the case of OECD countries such as Australia, Canada, Croatia, Denmark, Finland, Germany, Iceland, New Zealand, Norway, Sweden etc. - which are located in the high right part of the graph (log GDP per capita around 1.5 and gender gap above 0.7 ). Inversely, countries, in which the gender gap is high, have a low development index. This is the case of countries such as Afghanistan, Angola, Ethiopia, Mali, Nigeria, Turkey, Yemen, Zambia, 
Zimbabwe etc. - which are located in the low left part of the graph (log GDP per capita below 1 and gender gap between 0.46 and 0.64 )

In other words, countries with a higher status of women are richer; more developed and have fewer children. Inversely, countries with stronger gender disparities are poorer; less developed and have more children ${ }^{4}$.

\subsection{Demographic and Economic Long-run Trends}

Since the late eighteenth century, Europe experienced major economic and demographic changes. The demographic transition occurred in Western countries simultaneously to the transition from stagnation to growth. This led researchers to investigate the causal relation between demographic and economic transition. What are the underlying forces behind economic and demographic development? What are the endogenous interactions between education and fertility that result in the phase transition ${ }^{5}$ ?

\subsubsection{Demographic Changes}

The typical pattern of demographic transition begins with a mortality decline followed by a decrease in fertility. At the last stage of the process both mortality and fertility remain in balance at low rates. For France, the pattern is somewhat different. Both mortality and fertility rates dropped simultaneously. Figure 4 gives a broad picture of French demographic experience on the period 1740-2010.

In more detail, Figure 4(a) shows that after a first phase of decrease during the early $19^{\text {th }}$ Century, French fertility stabilized before reaching a second phase of decline from the last quarter of the Century. Life expectancy at birth and infant mortality evolved symmetrically. As reported by Figure 4(b), life expectancy at birth started first to increase slowly and then at an increasing rate from the last decade of the $19^{\text {th }}$ Century (and remains always higher for women than for men), while by contrast, infant mortality dropped substantially at the same period.

\footnotetext{
4 Also documented by Klasen (2002), Dollar and Gatti (1999).

5 See Galor (2005) and Doepke (2007) for recent survey.
} 


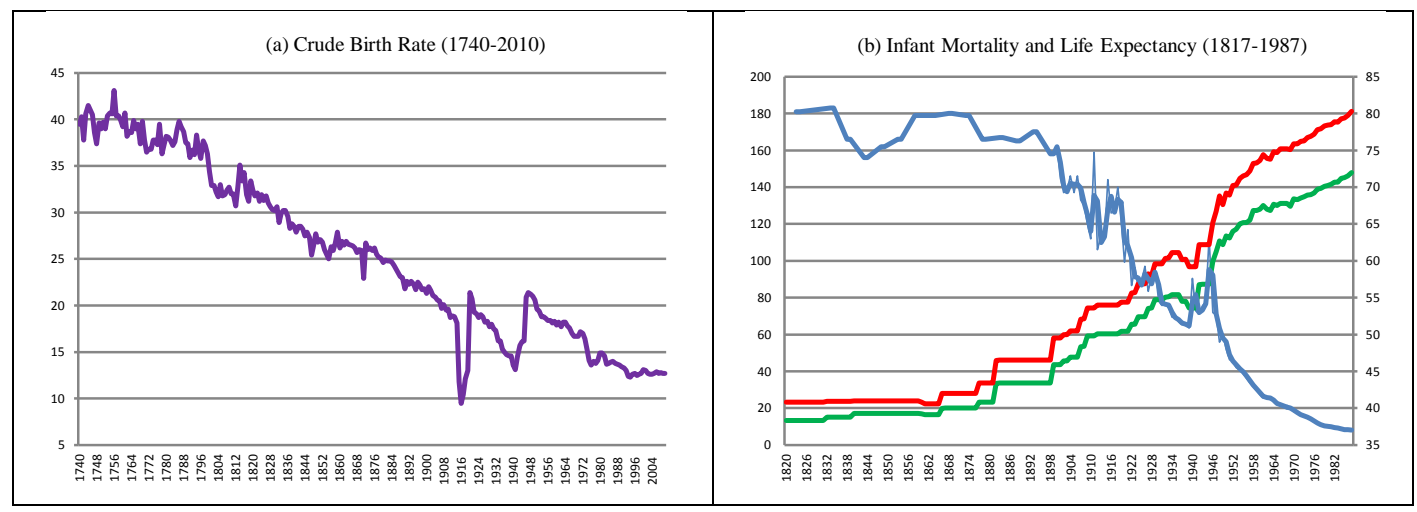

Figure 4. The Stylized Facts of Long-Run Demographic Changes, France

Notes: The crude birth rate and infant mortality data, respectively Figure 1(a) and 1(b), are taken from Chesnais (1992). Life expectancy at age 0 data in Figure 1(b) are taken from Insee (Bilan démographique, 2007). Missing intermediate values are obtained by linear interpolation.

Western countries' demographic profiles are similar but they witnessed the demographic transition with different synchronization. The comparison between the French and the English case constitutes an interesting paradox. While the Industrial Revolution begins in the $18^{\text {th }}$ Century and the demographic transition in the $19^{\text {th }}$ Century in England, inversely France experiences first its demographic revolution and then the Industrialization (Chesnais, 1992).

\subsubsection{Economic Changes}

France is thereby the first country to experience a fertility decline while GreatBritain is the first to experience the Industrial Revolution. The development pattern in France exhibits an increase in individual longevity, measured in terms of life expectancy at birth. The French transition scenario begins with a mortality decline which, very rapidly, is followed by a reduction in fertility. Owing to the onset of demographic changes, real product and per capita income levels start to increase slowly, and then face an extraordinary take-off in the second half of the $20^{\text {th }}$ Century. 


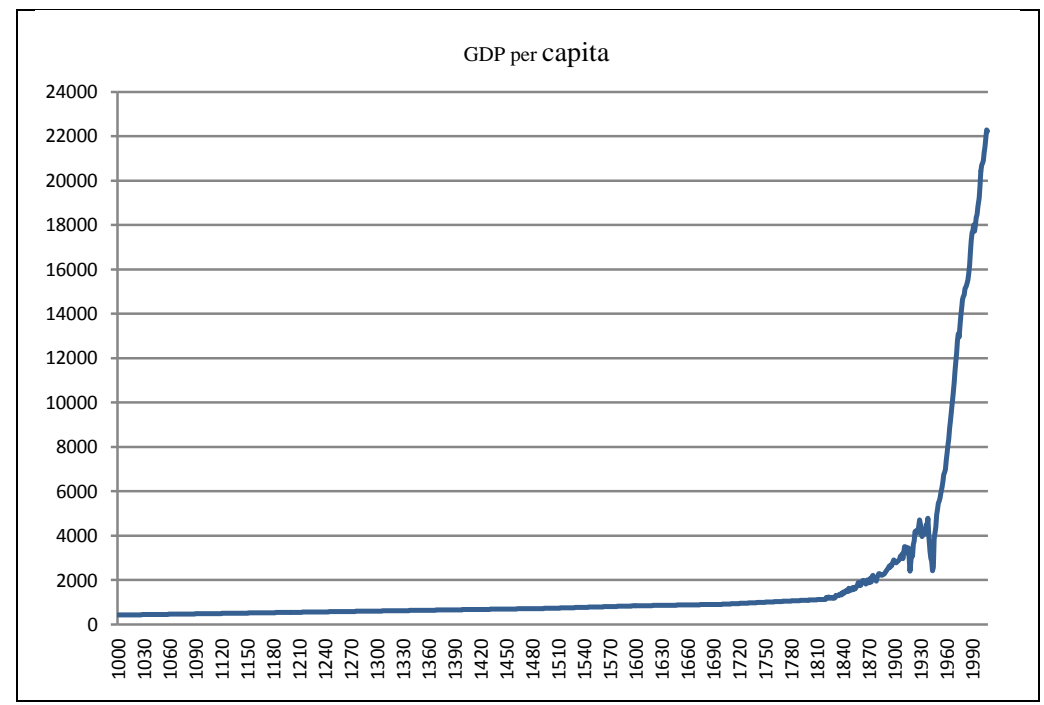

Figure 5. LONG-RUN ECONOMic CHANGES IN FRANCE (1000-2008)

Notes: The GDP per capita data are taken from Maddison (2008).

Therefore, in association with demographic changes (observed Figure 4) is the take-off of GDP per capita - the economic transition. As illustrated in Figure 5, France witnesses its economic transition from mid- $19^{\text {th }}$ Century; after a very long period of stagnation in income per capita. For comparison, the first case of economic transition occurred in England with the Industrial Revolution in the second half of the $18^{\text {th }}$ Century (see Cervellati and Sunde, 2005 - for more evidence on the English case).

\subsubsection{Educational Changes}

In addition, we note profound changes in the composition of the population, notably in the proportion of people acquiring formal education. While a huge proportion of the population was illiterate before the demographic and economic transition, only a very small fraction of people were still not able to read and write in the late $19^{\text {th }}$ Century (Figure 6(a)). During the different stages of transition, enrollment rates in primary and secondary schools increased dramatically for both boys and girls. Primary education rose significantly during $19^{\text {th }}$ Century, always in a stronger proportion for boys compared to that of girls (always one step ahead 
for boys' enrollment). In comparison, secondary education was delayed and less pronounced - almost absent for girls before 1881 - in a first step and increased drastically from the end of $19^{\text {th }}$ Century - as can be seen in Figure 6(b).

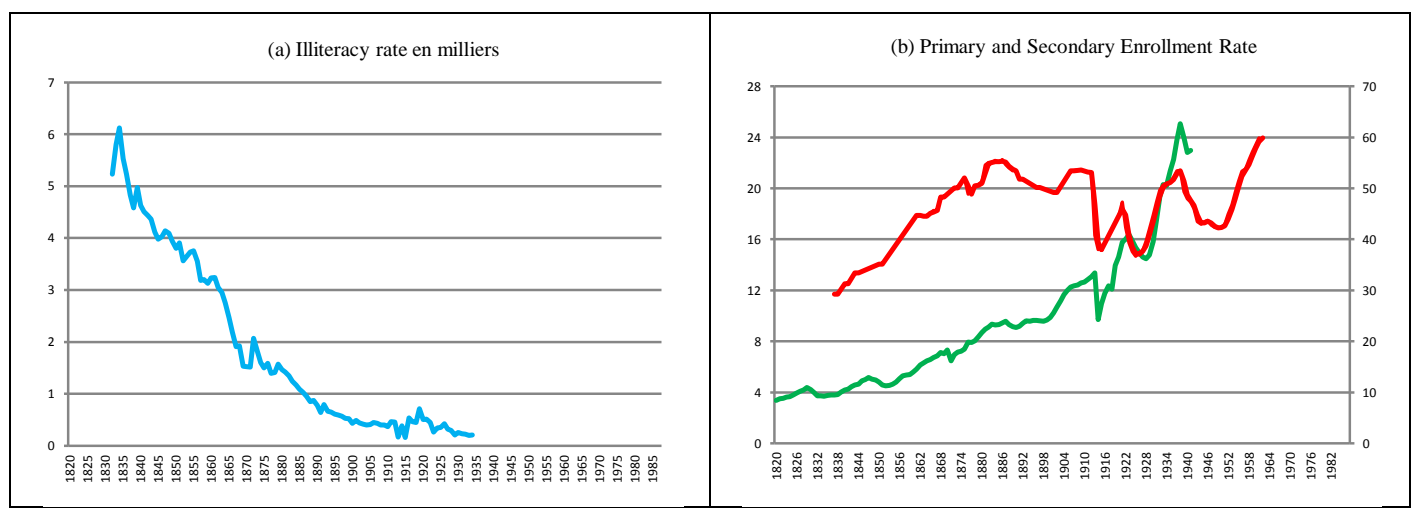

Figure 6. The Stylized Facts of Long-RUn Educational Changes, France (1817-1987)

Notes: The illiteracy rate consists in the share of illiterates - people unable to read and to write (taken from Blum and Houdaille). The boys and girls enrollment rates in primary and secondary schools data are taken from Diebolt. Missing intermediate values are obtained by linear interpolation.

Development patterns highlight a rapid increase in schooling enrollment rate for both boys and girls (at a faster rate for boys). While the vast majority of the population was illiterate before the economic and demographic transition, basic education, measured as the elementary school enrollment, increased substantially around the time of the take-off. Public secondary (Figure 6(b)) and high school enrollment was delayed but equally without precedent.

\subsection{Gender Relations over the Long-Run}

In parallel to demographic, economic and educational evolutions, we observe drastic changes in gender relations. Throughout history, women have always worked. However, the bargaining position of women within the household ${ }^{6}$,

\footnotetext{
6 Defined as a cooperative economic unit aimed at the fulfillment of the needs of its members (De Moor and van Zanden, 2009)
} 
evolved over time according to socio-economic and ideological factors ${ }^{7}$; impacting over time the structure of women's work.

\subsubsection{The Traditional Role of Women}

The sharp distinction between the role of wife and husband within the household arise in the $19^{\text {th }}$ century, when industrialization leads to a greater separation of home and professional sphere. The role of women in the workplace declines in comparison with previous periods. Women's reproductive duties occupy a significant share of their marital life. Thereby, the commonly accepted pattern as the most rational is that of men specialized in paid market work and women in unpaid reproductive and maintenance work in the domestic sphere. It is then very difficult, or impossible, for women to achieve a high position in the labor market.

"As long as women bear a disproportionate burden in raising children, the labor market will reflect these differences." (Goldin, 1990)

The organization of the society, dividing the work by gender and confining women inside the family in a situation of economic dependency and of subordination to men dominated most human history. This pattern, based on the existence of a clear demarcation between family and labor market is the result of a division of labor between gender aiming to combine the possibility of having a maximum of children and income within the household, the so-called patriarchal model.

\subsubsection{The Emergence of New Economic Role of Women}

The access for single women to salaried jobs in western countries starts during the 19th century. The vast majority of women workers are poorly educated. The access for married women, particularly those with young children, into the labor force only arise from the early $20^{\text {th }}$ century, in parallel to the increase in technological progress in the market sector and in household production technology (basic facilities). From around the 1930s, the labor force participation

\footnotetext{
${ }^{7}$ Such as new religious movements, institutional changes/law (inheritance systems) or the access to the labor market (see De Moor and van Zanden, 2009)
} 
of married women increases substantially. Nevertheless, despite the time saved achieving domestic duties and the access for women to paid jobs, women's employments remains concentrated in sectors requiring few qualifications, in the continuity of domestic labor, and offering low wages ${ }^{8}$.

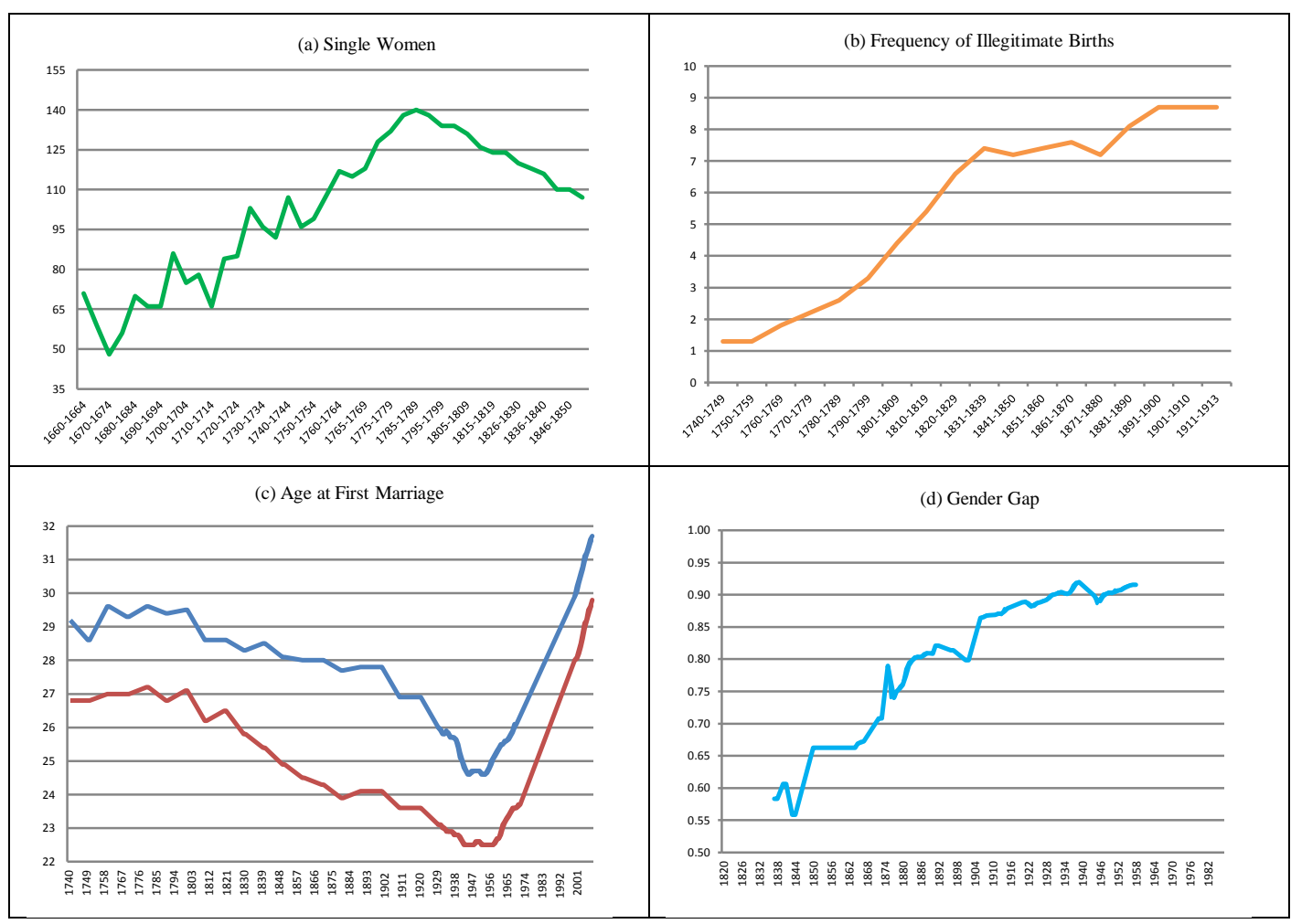

Figure 7. The Stylized Facts of Long-RUn Gender Relations, France

Notes: Data about the share of single women aged 50 and above (Figure 7(a)) and Age at first marriage (Figure 7(c)) come from Henri and Houdaille (1978, 1979). Data about the frequency of illegitimate births (Figure 7(b)) are taken from Fine (1988). The gender gap index (Figure 7(d)) consists in the female-to-male enrollment rate in primary school, data taken from Diebolt. Missing intermediate values are obtained by linear interpolation.

According to Hajnal (1965), three principal features emerge from the Western European Marriage Pattern (EMP) which characterized western society in the Early Modern Period: a high proportion of females never marrying a low rate of illegitimate births and an unusually late age at first marriage for females. Figure 7 offers a brief picture of a set of related changes in the French case. The number of

\footnotetext{
${ }^{8}$ The average married women workers were less educated than the average population.
} 
single women (women never marrying) increases substantially from the mid $17^{\text {th }}$ century until to the French Revolution (at the end of the $18^{\text {th }}$ century); period from which the trend experiences a complete reversal (Figure 7(a)). The frequency of illegitimate birth increases sharply between the mid $18^{\text {th }}$ century and the beginning of the $20^{\text {th }}$ century. Close from $1 \%$ on the period $1740-45$, it reaches almost 9\% in 1911-13 (Figure 7(b)). Finally, the long-run evolution of the median age at first marriage for both males and females follows a U-shaped curve. Relatively late during the second half of the $18^{\text {th }}$ century (around 27 for females and above 29 for males), it drops at the turn of the $19^{\text {th }}$ century; to a greater extend for women. The age at first marriage attains the lowest points in the 1950s with 22.5 and 24.6 before experiencing a sharp reversal and to reach almost 30 and 32 in 2001, respectively for females and males (Figure 7(c)).

The marriage pattern found in Western Europe seemed as having possibly stimulated the investment in human capital for both men and women and participated to changes gender relations. Figure 7(d) displays the evolution of the gender gap index measured as the female-to-male enrollment in public primary school. While at the beginning of the period the gender gap index is relatively low around 0.56 , at the end of the period it reaches around $0.92^{9}$.

The implications of the marriage pattern highlight a relatively more equal position between men and women within the household, notably due to the integration of women into market activities. The marriage pattern could be considered as having built the foundations of the female emancipation movement which occurred during the $19^{\text {th }}$ and $20^{\text {th }}$ Century.

\subsubsection{The "Quiet Revolution" 10 "}

The situation starts to change deeply from the middle of the sixties. Violent protests from the United-States and Sweden are at the origin of a veritable cultural revolution in western countries, transforming profoundly the status of women in the society. Part of the economic, social and cultural upheaval of the $20^{\text {th }}$ century in western countries is undoubtedly attributable to the control of procreation ${ }^{11}$ and to the legalization of abortion.

\footnotetext{
9 An index equal to 0 means perfect inequality between boys and girls. The perfect equality between boys and girls is characterized by a gender gap index equal to 1 .

10 Goldin, 2006.

11 In 1956, the combined oral contraceptive pill, or birth-control pill, is developed by the doctor Gregory Pincus.
} 
Many fundamental changes occurred in women's life. Reliable and easy to use, the Pill plays a decisive role in the decision of millions of women to invest in long-run vocational training and to build careers without having to pay high social costs in case of unplanned pregnancies (Goldin and Katz, 2001). In addition to financial costs of education and short run income loss, women who choose to invest in education have also to take into account social consequences of their decision.

Time represents for women a real constraint. The time of schooling has to be managed simultaneously to that of professionalization and the project of having children (Langevin, 1984). The plurality of this pattern that has widely dominated in our society implied for women to elaborate real strategies of conciliation between professional and family roles (Commaille, 1992). If men's career is positively correlated with the fact of being married and having children, in contrast, women's career is negatively associated. Women have to face a tradeoff: either they choose to privilege first their professional career, delay childbearing and have more chances to get a stable job, losing in the same time opportunities to have children (because of the decrease in fertility after thirty years old), either they first privilege family by having children but as a consequence will have in majority an unstable job (as partial time) or will even renounce to work on the labor market (Pailhé and Solaz, 2007).

The time constraint is a real obstacle for women's career. Invisible and artificial barriers created by behavioral and organizational prejudices prevent women to reach the highest responsibilities in the professional sphere (BIT, 1997). This is the process of women empowerment that marks the rise toward a new family organization (toward a modern economic role of women), that will ultimately lead women to integrate massively higher paid-jobs. Between 1975 and 2005, the female labor force increases for all age groups, except for the 12-24 because of the increase in schooling. With more accurate expectations, girls can better prepare their educational investments. At the same time (since the end of the sixties), the female average wage improves strongly, and at an increasingly rate from the eighties thanks to a better training of girls and due to the generalization of stable jobs.

In developed countries, the increase in female investments in education changes deeply the nature of available work for women. The dominant model becomes the expression of a rapprochement and a homogenization of males' and females' behavior/decisions regarding their activity (Maruani, 1996). Henceforth, 
women do not stop anymore their professional activity on the occasion of the birth of their children. There is no more choice, neither alternation, but a plurality between family and professional spheres: this is the blossoming of the dualearning model. Each member of the household pursues a professional career, inducing a higher standard of living ${ }^{12}$.

Human history can be clearly divided into two distinct eras. Before the Industrial Revolution all societies were characterized by a very long period of stagnation in per capita income with high fertility rates, the dominance of physical over human capital and strong gender gap. Since this fateful period, Western countries have observed a complete reversal with a high sustained income per capita, low fertility, human capital as an important source of income and improvement in gender equality.

Central to this paper is the consideration that the stylized facts of the development pattern, characterizing western society, are linked with households' behavioral patterns and more specifically with the changing economic role of married women over time (based on the evolution of gender relations/powerimbalance between generations and sexes).

\section{Related Literature}

If empirical literature on the link between gender equality and economic development is rather abundant (Schultz, 1995; Klasen, 2002; Knowles, Lorgelly and Owen, 2002 among many others), theoretical literature remains scarce. Galor and Weil (1996) or Lagerlöf (2003) are part of the few growth theorists, having integrated gender differentiation in their model.

\subsection{Theoretical Foundations of the Development Process}

Theories which aim to explain economic growth and development have for a long time been inspired by Malthusian and Neoclassical conceptions (Solow).

World economic history has been dominated by the Malthusian stagnation. The

\footnotetext{
12 Let's note that men and women always achieve unevenly domestic duties - around 30\% to $50 \%$ for men and $50 \%$ to $70 \%$ for women.
} 
Classical growth theory developed by Malthus in 1798 in An Essay on Principle of Population matches pretty well with empirical evidences of the relation between income and population dynamics prior to the Industrial Revolution. According to this theory, the effect of population growth would be counterbalanced by the expansion of resources, reflecting in such a way the fluctuations of the income per capita around a subsistence level. In other words, without changes in the level of technology (resources) the population size would remain stable as well as the income per capita, while periods of technological progress (expansion of resources) would lead to an increase in population growth, triggering ultimately a decline in income per capita. Despite the capacity of the Malthusian theory to capture the characteristics of the epoch of stagnation, its predictions appear inconsistent with the features of the post-demographic transition era as well as that of the modern growth regime.

Exogenous growth models such as Solow's model (1956) deal with demographic growth as an exogenous variable and assume that demographic behaviors are independent of wages, incomes and prices. Without technological progress, the income per capita converges toward a stable steady-state independently of the size of the population. The lack of consideration of family behavior and its impacts led to the creation of a new stream of research: the "New Home Economics" (Becker, Mincer). This latter extends the domain of microeconomic analysis to a wide range of behavior and human interaction, such as demographic behavior, investments in human capital, intergenerational transfers and so on (including the distribution of work and allocation of time in the family).

A decade later, Nerlove (1970), Razin and Ben-Zion (1975) or Srinivasan (1988) link demographic behaviors to macroeconomic evolutions in order to analyze their implications on the general equilibrium ${ }^{13}$. Inspirited by these papers and by the endogenous growth models of Romer (1986, 1990) and Lucas (1988), growth models with explicit microeconomic foundations of family have then progressively been developed (Barro and Becker, 1990; Becker, Murphy and Tamura, 1990; Ehrlich and Lui, 1991; Galor and Weil, 1996; Dahan and Tsiddon, 1998; Iyigun, 2000).

\footnotetext{
13 Within the framework of neoclassical growth model with endogenous fertility, the authors attempt to determine the optimal population growth rate.
} 


\subsection{Theories of Demographic Transition}

From a theoretical point of view, different factors could have triggered a demographic transition, i.e. a period of significant reduction in fertility rates and population growth following the unprecedented increase in population growth.

Theorists have examined a set of plausible explanations being at the root of the demographic transition and the reversal in the relation between income and population growth. Among these potential factors, we came across the decline in child mortality rates leading to a corresponding decrease in total fertility rates. Some researchers (Becker, 1981) argued also that the rise in per capita income had an effect on both the household's income and the opportunity cost of raising children. In both cases, historical (and empirical) evidences contradict these potentialities. First, in Western countries the decline in mortality started a century before the decline in fertility. Secondly, the demographic transition occurs simultaneously across countries that significantly differ in their income per capita.

The gradual rise in the demand for human capital along the process of industrialization has been seen by some researchers as a prime force leading to the onset of the demographic transition, specifically during the second phase of the Industrial Revolution. Taking family as a single decision-maker, Becker models manage to generate the demographic transition but do not differentiate between the behaviors of males and females. Becker et al. (1990) study model the relationship between human capital, fertility and economic growth. In this "one sex" model with altruistic parents, higher productivity leads to higher wages and favors human capital accumulation which in turn raises the opportunity cost of children. This feature highlights the existence of two locally stable steady-states: a Malthusian steady-state with many children and little human capital and a steadystate with few children and high human capital (same result in Tamura, 1994). In the interpretation of the model, they consider changes in female labor force as implicit.

The decline in the gender gap is another argument advanced as a reinforcing mechanism impacting fertility rates. Galor and Weil (1996) investigate the relationship between fertility, gender gap in wages and economic growth by assuming explicitly that men and women have different abilities and do different kinds of work. According to Galor and Weil, technological progress and capital accumulation positively impact the relative wages of women along the process of industrialization which would increase the opportunity cost of raising children, 
and ultimately lead to a reduction in fertility. Iyigun and Walsh (2007) explain the decline in fertility through the evolution of the spousal bargaining power within the couples' decision-making problem.

The progress of neoclassical growth models with endogenous fertility may provide plausible explanations of the modern experience of economic growth in developed economies. Nonetheless, they do not provide a global understanding of the development process as a whole (mysteries persist about some of the most fundamental features of the process of development). This led growth theorists, such as Galor, to point out the importance of a theory that could captures in a single framework the transition from Malthusian stagnation to sustained economic growth, as well as the associated phenomenon of great divergence and demographic transition.

\subsection{The Unified Growth Theory}

Galor and Weil $(1999,2000)$ emphasize the existence of three stages within the development process: the Malthusian Era (stagnation), the Post-Malthusian Regime (take-off) and the Modern Growth Regime (sustained growth).

Figure 9 illustrates the evolution of the relationship between the growth rate of GDP per capita and population over the course of human history in Western countries. Three specific eras can be distinguished: the stagnation, the take-off and the sustained growth. During the period of stagnation, population growth was positively affected by the level of income per capita. The absence of significant changes in the level of technology trapped the income per capita around a subsistence level and population size remained relatively stable. As depicted by Maddison's data (2001), the average level of world per capita income fluctuated around $\$ 670$ per year from 1000 until the end of the $18^{\text {th }}$ century. The monotonic increase in income per capita during the Malthusian era was associated with such a uniform evolution of the average population growth rate in the world while it did not result in variations in the standard of living (Galor, 2011). 


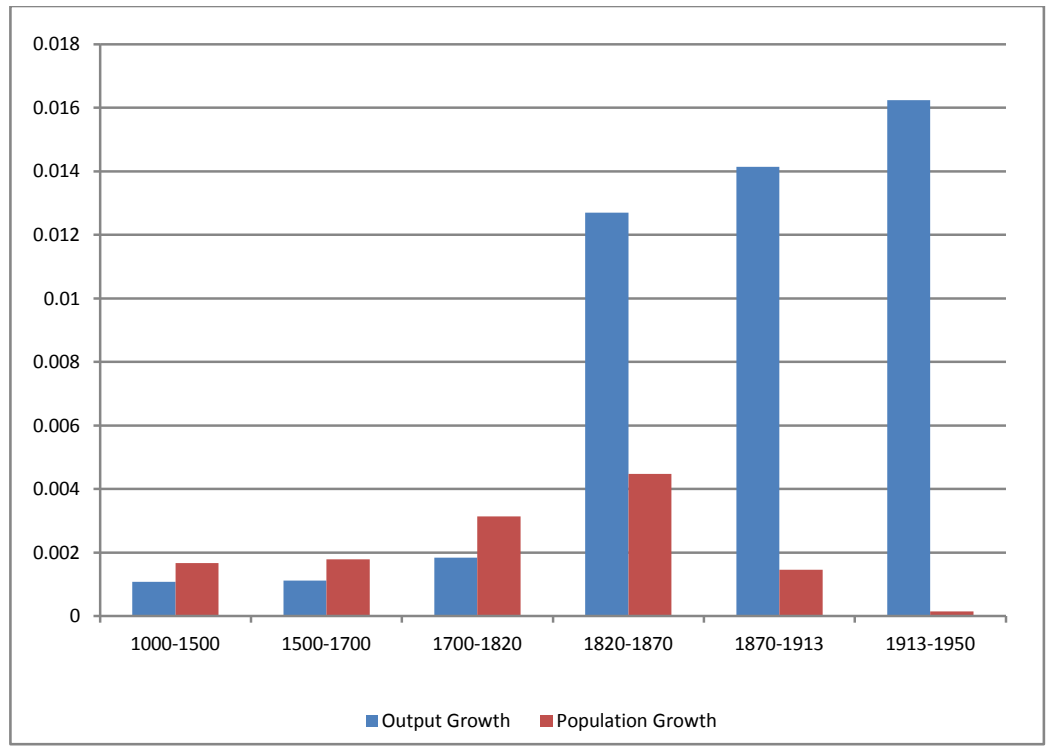

Figure 7. The Three Phases of the Development Process, France

Notes: Data from Maddison (2008).

Over the course of the $18^{\text {th }}$ and $19^{\text {th }}$ Century, Western countries experienced a take-off from Malthusian stagnation with different timings. This shift took place along with the increase in the pace of technological progress and marked the onset of the Industrial Revolution. During this period, income and population growth were still positively correlated. Thereby, the significant increase in the output growth has brought an unprecedented increase in population growth. Based on Maddison's data, the French average growth rate of output per capita increased from $0.17 \%$ per year for the period $1500-1820$ to $1.30 \%$ per year during the period $1820-1870$, and $1.20 \%$ per year in the years $1870-1913$. Similarly, the average rate of population growth in France increased continuously from 1500 to $1870(0.34 \%$ per year in the period $1500-1820,0.46 \%$ per year in the years 1820 1870). At the global level, output growth passed from $0.05 \%$ per year for the period $1500-1820$ to $0.54 \%$ per year during the period $1820-1870$, and reached $1.3 \%$ per year in the years 1870-1913. On the other side, world population growth increased (continuously as well) from 1500 to 1913 : 0.27\% per year in the period $1500-1820,0.4 \%$ per year in the years $1820-1870$, and to $0.8 \%$ per year in the interval 1870-1913. The timing of the take-off then differs across regions. In less 
developed countries ${ }^{14}$, the take-off occurred progressively with a one-century delay, from the beginning of the $20^{\text {th }}$ century. The decline in population growth marked the end of the so-called Post-Malthusian Regime towards the end of the $19^{\text {th }}$ century in Western countries and in the second half of the century in less developed regions.

The acceleration of the technological progress in the second phase of industrialization (second half of the $19^{\text {th }}$ Century), its interaction with the human capital accumulation and the reversal in the relation between income per capita and population growth signed the transition toward a state of sustained economic growth. The phenomenon of demographic transition occurred in the course of the last century as countries developed along the industrialization. This process accounts for the transition from high birth and death rates to low birth and death rates. In pre-industrial society, both death and birth rates fluctuated around a high level (depending on food supply, diseases, natural events...). During the $19^{\text {th }}$ century in Western countries, mortality rates dropped rapidly while birth rates remained high, involving an increase in population. In the following stage, birth rates fell and population growth began to level off. According to Maddison's data, a reversal in the rate of population growth occurred by the end of the $19^{\text {th }}$ centurybeginning of the $20^{\text {th }}$ century for particular regions of the world (Western Europe, Western Offshoots and Eastern Europe). Population growth decreased also in France (from an average of $0.18 \%$ of growth per year in the period $1870-1913$ to an average of $0.06 \%$ per year in the years 1913-1950), while it continued to grow in other parts of the world. At the same time, the world average growth rate of GDP per capita kept on increasing (reaching an average of $2.92 \%$ per year on the period 1950-1973).

Galor and Weil $(1999,2000)$ develop the idea that the acceleration in the rate of technological progress gradually increases the demand for human capital, inducing parents to invest in the quality of their offspring rather than in the quantity. The existence of a negative correlation between education and fertility has been demonstrated by Becker, Cinnirella and Woessmann (2011) with new county-level evidence for Prussia in 1816. Ultimately, the process of human capital accumulation induces a reduction in fertility rates as far as the growth rate of technological progress increases. The model therefore generates a transition from the Malthusian stagnation to the Modern growth regime.

${ }^{14}$ By developed countries, we mean Latin America, Asia and Africa. 
As highlighted previously (section1), Western countries experienced similar patterns of economic and demographic transition, despite some variations in terms and timing and speed of changes (Galor, 2005b). The trends upheaval strongly question on the possible existence of an interaction between the rise in gender equality, decline in fertility, increase in human capital and the onset of sustained economic growth. Women related issues have become central to the field of labor economics and economic history (Goldin, 2006); nevertheless it remains rare in the field of economic growth. In what follows, we argue that relations between changes in gender relations and the process of development are strong and that theories of economic growth should account for gender empowerment as a key ingredient in the transition to sustained economic growth.

\section{The Model}

We consider an overlapping-generations model in which the activity extends over infinite continuous time, denoted by $T \in \mathbb{R}^{+}$. The economy is made up of a discrete number of overlapping generations. In every period, the economy produces a single homogenous good, using efficiency units of labor.

Each generation is populated by two kinds of individuals: males $(m)$ and females $(f)$. Each males and females are endowed with one unit of time that they split up between market work, education, having and rearing children. In the first period of life, individuals only consume a fraction of parental time endowment. We assume that the time cost of childbearing is greater for women ${ }^{15}$, so that $\tau^{f} \equiv \tau>\tau^{m}=0$ (as in Iyigun and Walsh, 2007), with $\tau$ the cost of rearing one child. In the second period of life, agents match (randomly) into couples with someone of the opposite sex belonging to the same generation. All adult-members of the households make decisions regarding their own education, work and fertility. Each household is therefore composed of several individuals: a man and a woman, with different preferences; and their children. Men and women of generation $t$ face a deterministic level of gender equality $\theta_{t}$.

\footnotetext{
15 A recent study of the Observatoire des inégalités (using the Insee "Emploi du temps 2009-2010" survey) shows that women still spend twice more time than men taking care and rearing children.
} 


\subsection{Production}

\subsubsection{Production of Final Output}

The production occurs according to a constant-return-to-scale technology that is subject to endogenous technological progress. The unique consumption good (output) is produced using two factors of production: skilled labor $\left(L^{S}\right)^{16}$ and unskilled labor $\left(L^{u}\right)$. The aggregate production function at time $t, Y_{t}$, is given by the following CES production function:

$$
Y_{t}=A_{t} Y\left(L^{u}, L^{s}\right)=A_{t}\left[\left(1-\alpha_{t}\right) L_{t}^{u \rho}+\alpha_{t} L_{t}^{s}\right]^{\frac{1}{\rho}}
$$

where $\alpha_{t} \in(0,1)$ is the relative productivity share, $A>0$ represents the endogenously determined technological level at time $t$ (total factor productivity) and $\rho \in(0,1)$. All factors of production are assumed to earn their marginal products. The returns from each type of labor at time $t$, respectively unskilled labor, $w_{t}^{u}$, and skilled labor, $w_{t}^{s}$, are:

$$
\begin{aligned}
& w_{t}^{u}=\frac{\partial Y_{t}}{\partial L_{t}^{u}}=A_{t}\left(1-\alpha_{t}\right) L_{t}^{u \rho-1}\left[\alpha_{t} L_{t}^{s \rho}+\left(1-\alpha_{t}\right) L_{t}^{u \rho}\right]^{(1-\rho) / \rho}, \\
& w_{t}^{S}=\frac{\partial Y_{t}}{\partial L_{t}^{s}}=A_{t}\left(\alpha_{t}\right) L_{t}^{s \rho-1}\left[\alpha_{t} L_{t}^{s \rho}+\left(1-\alpha_{t}\right) L_{t}^{u \rho}\right]^{1-\rho} / \rho
\end{aligned}
$$

\subsubsection{The Production of Human Capital}

Human capital can be defined as the stock of (accumulated) knowledge, skills, competencies, attributes embodied in people that improve their ability to perform labor so as to produce economic value. The benefit from embodying additional knowledge in a person may depend positively on the knowledge he or she already has (Becker, Murphy and Tamura, 1990). In order to earn an income $y_{t}^{i}$ and to consume, individuals have to acquire human capital and supplied this human capital to the labor market. The acquisition of human capital requires time. We

${ }^{16}$ Skilled labor constitutes adult workers who have invested a fraction of time in schooling when young. 
model the production of human capital as the outcome of an education process involving decisions of parental (maternal) investments in education and of individuals themselves in their own education.

At birth, every individual is endowed with a certain amount of incorporated form of cultural capital, $h_{t-1} \in[0,1]$. This cultural capital is characterized by a set of intellectual qualifications resulting from family environment, and more specifically from parental endowment in human capital. Human capital can be accumulated over time through the education process (that is the institutionalized form of human capital). The effect of parental human capital is reflected by the higher productivity of the share of time unit spent by children in education. The amount of human capital acquired throughout the education process depends therefore on parental endowment in human capital. The larger the human capital embodied in parents $\left(h_{t-1}^{i}\right)$, the larger the effectiveness of the education process, and the larger the impact on resulting human capital $\left(h_{t}^{i}\right)$.

We assume that the time cost of childbearing is greater for women so that $\tau^{f} \equiv \tau>\tau^{m}=0$, with $\tau$ the cost of rearing one child. Therefore, it results that the human capital of each child depends on the incorporated form of human capital of its mother (maternal endowment in human capital) rather than of its father.

We denote $e_{t}^{i}$ the amount of time invested by an individual in his own education in either type of human capital, $i=u, s$, unskilled or skilled ${ }^{17}$. The education process differs between these two types of human capital with respect to the time intensity of the education process. There exists a fix cost $\underline{e}$ (in terms of time units) that agents need to pay when acquiring human capital ${ }^{18}$. The acquisition of skilled human capital involves a larger fix cost of education than the acquisition of unskilled human capital, $\underline{e}^{s}>\underline{e}^{u}$. As a consequence, the number of year spent working is also lower for a skilled individual. We assume that cultural capital (maternal endowment in human capital) is more important when acquiring advanced skills. For simplicity, we assume that $h_{t-1}^{f, s}=h$ and $h_{t-1}^{f, u}=1$.

The human capital production function can be written as follows:

$$
h_{t}^{i}=\beta^{i}\left(e_{t}^{i}-\underline{e}^{i}\right)\left[h_{t-1}^{f, i}\right]
$$

17 Galor and Moav (2002) introduce a quality type $a$ and a quantity type $b$ of adult individuals as a determinant of offspring's quality.

${ }^{18}$ Such as in Cervellati and Sunde (2007). 
with $\forall e \geq \underline{e}^{i} ; i=u, s$ and $\beta$, the productivity of a unit of education.

An individual that have received an inherited human capital of type $i$ and acquired human capital by investing $e_{t}^{i}$ in education of type $i$ can earn the lifetime income $y_{t}^{i}(h)$, such that :

$$
y_{t}^{i} \equiv y_{t}^{i}\left(h, e_{t}^{i}\right)=w_{t} h_{t}^{i}\left(h, e_{t}^{i}\right)\left[1-e_{t}^{i}\right]
$$

The lifetime income results from supplying human capital on the labor market, itself function of maternal human capital. A World Development Report already emphasized in 1993 the importance of women's income on children welfare. The report highlights a stronger effect of the income of mothers on the welfare of children than does an increase in the husbands' income. The concept of human capital (quality) in addition to abilities, competencies or knowledge embodied in individuals also includes health. Educational investment is a source of labor productivity that positively impact wages. Through this channel, it is very likely that women education also have a stronger effect on children's health than do men education (see Currie and Moretti, 2003).

\subsubsection{Technological Progress}

The technology evolves endogenously. Technological progress is assumed to raise the value of education in the production of human capital ${ }^{19}$. According to Lucas (1988) and Romer (1990), human capital accumulation is an engine of growth. It occurs through the acquisition of education and training which increases the skills and the productivity of the labor force (and promotes the adoption of new ideas and technologies). This implies that technological progress is biased toward high-skill intensive production and depends on the stock of human capital available in the economy. The arrival of new technologies involves larger factor productivity.

$$
g_{t}=\frac{A_{t}-A_{t-1}}{A_{t-1}}=F\left(\Lambda_{t-1}, A_{t-1}\right)
$$

\footnotetext{
19 Technological progress reduces the adaptability of existing human capital for the new technological environment. Education lessens the adverse effect of technological progress.
} 
The more individuals of a generation invest in skilled education, the more effective is the accumulation of skilled human capital for future generations.

\subsection{Individuals}

The members of generation $t$ lives for two periods: childhood and adulthood. In the first period of life, individuals are children. They consume a fraction of the parental time endowment. We assume that individuals make no decisions during childhood but they receive parental education. In the second period of life (adulthood), individuals make decisions regarding their own education and fertility (time invested in having and rearing children). The remaining period of time is spent on the labor market (either as skilled or unskilled worker).

As already stated previously, agents of both genders are assumed to be identical except in their time constraint, in that only women endorse the time cost of childbearing. In the model, women decide endogenously what portion of their lifetime to devote to child rearing. Throughout their strategies of life, females choose the optimal mixture of quantity and quality of children ${ }^{20}$ and allocate the rest of their time working on the labor market and consuming their wage. The number of efficiency units of labor is therefore determined by individuals regarding their level of human capital, and number of children.

\subsubsection{Preferences and Budget Constraint}

Multi-person Dimension Household. - We assume that all individuals get married in the second period of life. The utility function captures the two-sex dimension of the household. Individuals care about their own consumption and about the potential lifetime income of their children $^{21}$. Household preferences are represented by the following weighted utility function, which is monotonically increasing, concave and satisfies the standard boundary conditions insuring interior solutions,

$$
U\left(c_{t}^{m}, c_{t}^{f}, y_{t+1} n_{t}^{i}\right)=\left(1-\theta_{t}\right) \ln c_{t}^{m}+\theta_{t} \ln c_{t}^{f}+\gamma \ln \left(y_{t+1}^{i} n_{t}^{i}\right)
$$

\footnotetext{
${ }^{20}$ We will talk here about fertility as quantity and human capital as quality.

21 The utility function reflects the trade-off between the resources devoted to own consumption and to raise children.
} 
where $c_{t}^{f}$ and $c_{t}^{m}$ represent respectively the consumption level of the female (wife) and of the male (husband), $n_{t}^{i}$ is the total number of children of the couple, $y_{t+1}^{i}$ denotes the lifetime income of children $^{22}, \gamma \in(0,1)$ measures the value attached to the number of offspring relative to the labor-force participation and $\theta_{t}$ represents the female bargaining power within the household decision process.

The bargaining power of the wife in the household decision process is endogenous and assumed to be a function of human capital stock of the spouses. It shows how human capital affects the bargaining power of the female in the decision process. This parameter can be interpreted as a measure of gender equality within the household and is given by:

$$
\theta_{t}=\frac{w_{t}^{f} h_{t}^{f}}{w_{t}^{f} h_{t}^{f}+w_{t}^{m} h_{t}^{m}} \equiv \varphi\left(h_{t}^{f}, h_{t}^{m}\right)
$$

with $h_{t}^{f}$ and $h_{t}^{m}$, respectively, the female and male endowment in human capital. $\theta_{t} \in(0,1), \theta_{t}=0$ implies total decision-making power for the husband within the household, $\theta_{t}=1$ total power for the wife and $\theta_{t}=0$ characterizes a perfect equality within the couple (the perfect equality between spouses is reflected by $\left.\theta_{t}=1 / 2\right)$.

Budget Constraint. - Individuals consume according to the time spent on the market. For women, investment in own education and raising children represent costs in terms of time, time which is not available for market work. Let $\tau n_{t}^{i}+e_{t}^{f, i}$ be the time cost for a female member of generation $t$ of raising a children, getting a level of education $e_{t}^{i}$ of type $i$. Thereby, the time spent by women on the labor market is what remains after investing in education and raising children. Men only face a cost of time in terms of education. The time spent by men on the labor market is what remains after getting educated. Let $e_{t}^{m, i}$ be the time cost for a male member of generation $t$ of getting a level of education $e_{t}^{i}$ of type $i$. The potential income of men and women is allocated to the consumption, respectively $c_{t}^{m}$ and $c_{t}^{f}$. Wife and husband jointly face the following budget constraint, integrating individual time constraints:

\footnotetext{
22 This generates a link between generations (altruistic preferences).
} 


$$
c_{t}^{m}+c_{t}^{f} \leq\left(1-\tau n_{t}^{i}-e_{t}^{f, i}\right) w_{t}^{f, i} h_{t}^{f, i}(\cdot)+\left(1-e_{t}^{m, i}\right) w_{t}^{m, i} h_{t}^{m, i}(\cdot),
$$

Similarly to Becker (1960), Barro and Becker (1989) and Galor and Weil (2000), our model integrates quantity-quality considerations as the household chooses the number of children and their quality, regarding the constraint on the total amount of time individuals can devote to raise children and to work on the labor market. However, unlike existing models, the trade-off relies here on females' decisions making in the face of the trade-off between fertility and own investment in education.

\subsubsection{The Household Choice Problem}

Optimization Problem. - Members of a household of generation $t$ have to choose the type of human capital (through educational investments) they want to acquire, the number of offspring and their own consumption. In period $t$, the household solves the following optimization program:

$$
\left\{e_{t}^{f i *}, e_{t}^{m i *}, n_{t}^{i *}, c_{t}^{f *}, c_{t}^{m *}\right\}=\operatorname{argmax} U_{t}\left(c_{t}^{f *}, c_{t}^{m *}, y_{t+1}^{i} n_{t}^{i}\right)
$$

subject to:

$$
c_{t}^{m}+c_{t}^{f} \leq\left(1-\tau n_{t}^{i}-e_{t}^{f, i}\right) w_{t}^{f, i} h_{t}^{f, i}+\left(1-e_{t}^{m, i}\right) w_{t}^{m, i} h_{t}^{m, i},
$$

(4) and (5) for $i=u, s$

We derive the optimal choice and we get the following set of first order conditions with respect to the spousal consumption levels, optimal fertility and optimal investment in education, conditional to the acquisition of a particular type of human capital, $i$, given by:

$$
\begin{aligned}
& c_{t}^{m}=\left(1-\theta_{t}\right)\left[\left(1-\tau n_{t}^{i}-e_{t}^{f, i}\right) w_{t}^{f, i} h_{t}^{f, i}+\left(1-e_{t}^{m, i}\right) w_{t}^{m, i} h_{t}^{m, i}\right] \\
& c_{t}^{f}=\theta_{t}\left[\left(1-\tau n_{t}^{i}-e_{t}^{f, i}\right) w_{t}^{f, i} h_{t}^{f, i}+\left(1-e_{t}^{m, i}\right) w_{t}^{m, i} h_{t}^{m, i}\right], \\
& e_{t}^{m, i}=\frac{1+\underline{e}^{i}}{2}
\end{aligned}
$$




$$
\begin{aligned}
& e_{t}^{f, i}=\frac{1+\underline{e}^{i}-\tau n_{t}^{i}}{2}, \\
& n_{t}^{i}=\frac{\gamma}{\left(1-\theta_{t}\right)} \frac{c_{t}^{m}}{\tau w_{t}^{f, i} h_{t}^{f, i}},
\end{aligned}
$$

The first order conditions illustrate that the consumption levels of the husband and the wife are proportional. Everything else equal that: the trade-off faced by women between acquisition of own human capital and fertility implies that the optimal number of children is decreasing with the time invested by women in education. Thereby, having more children decreases the time invested in own education for women. In addition, a higher fix cost of education with the acquisition of skilled human capital requires a larger time investment in education.

Optimal Solutions. - The household optimal choices of $c^{f}, c^{m}, n, e^{f}, e^{m}$ conditional to the type human capital acquired is obtained solving the system of equation. We can establish that:

Consumption levels of the husband and the wife are proportional and depend on the bargaining power distribution within the household.

$$
\begin{gathered}
c_{t}^{m *}=\frac{\left(1-\theta_{t}\right)\left(1-\underline{e}^{i}\right)}{(2+\gamma)}\left(w_{t}^{f, i} h_{t}^{f, i}+w_{t}^{m, i} h_{t}^{m, i}\right), \\
c_{t}^{f *}=\frac{\theta_{t}\left(1-\underline{e}^{i}\right)}{(2+\gamma)}\left(w_{t}^{f, i} h_{t}^{f, i}+w_{t}^{m, i} h_{t}^{m, i}\right),
\end{gathered}
$$

The female optimal consumption is increasing with the female marital bargaining power. On the contrary, the male optimal consumption is decreasing with the female bargaining power. Each spouses contributes to a fraction of the household labor earning according to the value of the parameter $\theta_{t}$. In other words, the distribution of the consumption between spouses is function of the level of gender equality within the household.

At the extreme case $\theta_{t}=0$, for instance, the husband contributes fully to the household labor earnings; There is a strong gender gap between spouses. In the 
opposite case, since $\theta_{t}=1 / 2$ - there is perfect gender equality, both spouses contribute equitably to the household labor earnings.

Educational optimal choices for both member of the household are given by the following equations:

$$
\begin{gathered}
e_{t}^{m *}=\frac{1+\underline{e}^{i}}{2} \\
e_{t}^{f *}=\frac{\left(1+\underline{e}^{i}\right)}{2}-\frac{\gamma\left(1-\underline{e}^{i}\right)}{2 \theta_{t}(2+\gamma)}=e_{t}^{m *}-\frac{\gamma\left(1-\underline{e}^{i}\right)}{2 \theta_{t}(2+\gamma)}
\end{gathered}
$$

Male optimal level of education is function of the fix time cost of education. A higher cost of education in terms of time units requires a larger time investment in education. The optimal female education displays a similar positive impact of the educational cost on the amount of time invested in education. In addition, female optimal education is increasing with the female marital bargaining power. Stronger is the power of the wife within the household, higher is the time she invests in education.

The household optimal fertility is given by:

$$
n_{t}^{i *}=\frac{\gamma\left(1-\underline{e}^{i}\right)}{\tau(2+\gamma)} \frac{\left(w_{t}^{f, i} h_{t}^{f, i}+w_{t}^{m, i} h_{t}^{m, i}\right)}{w_{t}^{f, i} h_{t}^{f, i}} \equiv \frac{\gamma\left(1-\underline{e}^{i}\right)}{\theta_{t} \tau(2+\gamma)},
$$

The inspection of the optimal fertility choice of the household highlights the central role played by the wife within the household decision-making. The optimal fertility is decreasing with the female marital bargaining power. Lower is the bargaining power (male-breadwinner model) of the wife within the household, higher is the number of offspring. Inversely, higher is the gender equality (dualearning model), lower is the optimal number of children. Furthermore, we note from the equation (3.20) the existence of a negative relationship between quantity and quality of children. The fix cost of education impacts negatively the optimal number of children.

\subsubsection{Choice of Human Capital and Fertility}


We consider two types of human capital: the skilled and the unskilled human capital, respectively "intellectual" and "manual" human capital. The choice between each type of human capital depends partly on the level of wages (so as on returns from education, technology). Substituting $e_{t}^{m, s *}$ and $e_{t}^{m, u *}$; as well as $e_{t}^{f, s *}$ and $e_{t}^{f, u *}$ in the expression of the human capital production function, we obtain the respective male and female levels of human capital:

$$
\begin{aligned}
& h_{t}^{m, i *}(h)=\beta^{i} \frac{\left(1-\underline{e}^{i}\right)}{2} h_{t-1}^{f, i}, \\
& h_{t}^{f, i *}(h)=\beta^{i} \frac{\left(1-\underline{e}^{i}\right)}{2}\left(1-\frac{\gamma}{\theta(2+\gamma)}\right) h_{t-1}^{f, i},
\end{aligned}
$$

For any male and female endowed with parental (maternal) human capital, $h$, there exists unique levels of education $e_{t}^{m, i *}$ and $e_{t}^{f, i *}$, and level of fertility $n_{t}^{i *}$ maximizing their utility, conditional to the type of human capital acquired. Individuals with higher maternal human capital have a comparative advantage in acquiring skilled human capital. Therefore, the amount of individuals endowed with skilled type of human capital increases in $h$. On the contrary, unskilled human capital does not depend on parental human capital. There exist a unique threshold of parental human capital, $\hat{h}_{t}$, such that individuals are indifferent between acquiring skilled or unskilled type of human capital (equalizes their utility).

$$
\hat{h}_{t}=\beta \frac{w_{t}^{u}}{w_{t}^{s}}\left(\frac{1-\underline{e}^{u}}{1-\underline{e}^{s}}\right)^{2+\gamma}
$$

For a given distribution of parental human capital $d(h)^{23}$, the threshold $\hat{h}$ determines the fraction of individuals that choose to acquire skilled human capital. This threshold is a monotonically increasing function of the relative wage between unskilled and skilled human capital, $\left(w_{t}^{u} / w_{t}^{s}\right)$.

$$
\left(1-\Lambda_{t}\right)=\int_{0}^{\hat{h}} d(h) d h=\hat{h} \text { and } \Lambda_{t}=\int_{\hat{h}}^{1} d(h) d h=(1-\hat{h}),
$$

${ }^{23} d(h)$ denotes the distribution of "cultural capital" within a given generation of new individuals. 
Thereby, all agents with $h>\widehat{h}$ acquire skilled human capital (a fraction $\Lambda_{t}$ of the population) while all agents with $h<\widehat{h}$ acquire unskilled human capital (a fraction $1-\Lambda_{t}$ of the population). Higher is the skilled wage, lower is the relative wage and bigger is the fraction of people acquiring skilled human capital. For any level of parental human capital there is a unique optimal level of education and level of fertility which maximize the utility function. According to equation (3.29) and (3.30), the acquisition of skilled rather than unskilled human capital induces individuals to spend more time on education $\left(e_{t}^{S *}>e_{t}^{u *}\right)$ and to have a lower number of children $\left(n_{t}^{s *}<n_{t}^{u *}\right)$. The difference of fertility obtained according to the type of education is one of the most (if not the most) fundamental ingredient in the model.

The maternal human capital is conditional to education and fertility choices which depend on cultural and technological environment. One of the key determinants of educational investments is the rate of technological progress. Through this channel, the rate of technological change affects gender roles by increasing female marital bargaining power (what drives to higher equality between men and women).

Choices of human capital type and optimal fertility are function of the time spent by individuals in education. The acquisition of skilled rather than unskilled human capital induces individuals to spend more time on skilled education and to have a lower number of children. Inversely, individuals choosing to invest in unskilled education have a higher number of children. Differential fertility emerges since the acquisition of skilled human capital induces girls to substitute utility from number of children with utility from consumption. Ultimately, this mechanism drives to a fertility transition.

The threshold level of parental human capital making an individual indifferent between acquiring skilled or unskilled human capital, $\widehat{h}_{t}$, is decreasing in gender equality $\theta$. It induces a larger share of the population to optimally acquire formal education $\Lambda_{t}$. Any change in the fraction of individuals acquiring skilled and unskilled human capital (skill composition of the population, $\Lambda_{t}$ ) impacts the average fertility of the population. For any $\left\{A_{t}, \theta_{t}, g_{t}\right\}$, the average fertility is given by the following equation:

$$
n_{t}^{i *}=\left(1-\Lambda_{t}\right) n_{t}^{u}+\Lambda_{t} n_{t}^{s} \equiv \frac{\gamma}{(2+\gamma)} \frac{\left(1-\underline{e}^{u}\left(1-\Lambda_{t}\right)-\Lambda_{t} \underline{e}^{s}\right)}{\tau \theta_{t}}
$$


with $\frac{\partial n_{t}^{*}}{\partial \theta_{t}}<0$.

Gender equality is a key determinant of the average fertility. The fertility rate is negatively correlated with the level of gender equality within the population. Improvements in $\theta$ induce more people to acquire education (especially girls). Henceforth, improvements in gender equality induce a generalized decline in fertility. An economy with lower gender equality is characterized by lower fertility rate. Gender equality in the form of female marital bargaining power affects fertility by inducing a change in the female optimal choice of education time and in the type of education. Finally, an increase in female human capital is associated with reduction of the number of children and an increase in their quality. Associated together, the different effects of technological progress and gender equality can account for the demographic and the economic transition, such that fertility decreases, education expands and growth reaches a sustained level.

\subsection{Equilibrium}

The aggregate levels of each type of human capital are given by:

$$
\begin{aligned}
& L_{t}^{u}=H_{t}^{u}(\hat{h})=N_{t} \int_{0}^{\hat{h}} h_{t}^{u}(\hat{h}) d(h) d h, \\
& L_{t}^{s}=H_{t}^{s}(\widehat{h})=N_{t} \int_{\widehat{h}}^{1} h_{t}^{s}(\widehat{h}) d(h) d h,
\end{aligned}
$$

There exists a unique threshold of "cultural capital" (derived from maternal endowment in human capital) that splits the population between individuals acquiring skilled and unskilled human capital. From (2) and (3), we determine the unskilled-to-skilled wage rates on competitive markets.

$$
\frac{w_{t}^{u}}{w_{t}^{s}}=\frac{1-\alpha_{t}}{\alpha_{t}}\left(\frac{L_{t}^{u}}{L_{t}^{s}}\right)^{\rho-1}
$$


The wage rates ratio depends itself on the ratio of the aggregate level of unskilled and skilled human capital.

\section{The Dynamic Evolution of the Economy}

\subsection{Dynamic Evolution of the Key Variables}

The evolution of the economy is characterized by demographic and economic transitions. In particular, the development of the economy is characterized by the evolution of educated people, technological level and gender equality. The global dynamics of the economy is described by the trajectory of gender equality $\theta_{t}$, the share of the population acquiring skilled human capital $\Lambda_{t}$ and the total factor productivity. We can study the dynamic development of the economic by analyzing the evolution of the key state variables over generations. The evolution of the economy is fully described by a sequence $\left\{\Lambda_{t}, \theta_{t}, \alpha_{t}\right\}_{t=0}^{\infty}$, resulting from the evolution of the three-dimensional nonlinear first-order system.

\subsubsection{The Fraction of Skilled Individuals}

The equilibrium fraction of the population acquiring human capital is monotonically increasing in $\theta_{t}$. The higher the gender equality, the more people invest in the acquisition of skilled human capital. Intuitively, for low levels of gender equality the fraction of skilled individuals is small. There is no accumulation of human capital and the returns from investing in skilled education do not worth the effort. Very large improvements in gender equality are necessary to make individual invest in skilled education and then to allow for human capital accumulation. The equilibrium fraction of the population acquiring human capital also depends on the technological environment - is increasing in the relative productivity of skilled human capital intensive sector, $\alpha_{t}$. The labor market condition equilibrium is given by:

$$
\Lambda_{t}=\Lambda\left(\theta_{t}, \alpha_{t}\right)
$$

which is an increasing and S-shaped function of $\theta_{t}$. 


\subsubsection{Dynamic Evolution of Gender Equality}

Based on historical evidence, we suggest that gender equality is function of the stock of skilled human capital of spouses (measuring human capital on the bargaining power distribution), such that gender equality increases with individuals human capital. In particular, gender equality is linked with the distribution of knowledge embodied in individuals in the previous generation, $t-1$ (function of the average stock of female skilled human capital), through the time invested in skilled education $\left(e_{t-1}^{S}\right)$. The dynamic evolution of gender equality can be expressed as:

$$
\theta_{t}=\boldsymbol{\theta}\left(\theta_{t-1}, \Lambda_{t-1}\right)
$$

This expression involves that gender equality is increasing with the share of individuals (within the parental generation) acquiring skilled human capital.

\subsubsection{Process of Technological Process}

The process of technological change depends on the stock of skilled human capital (biased toward skill-intensive sector of production). The available stock of human capital in a generation $t$ makes human capital more profitable to acquire for future generations. The dynamic evolution of technological progress is given by:

$$
g_{t}=\boldsymbol{G}\left(\Lambda_{t-1}, A_{t-1}\right) \text {, }
$$

which implies that the productivity $A_{t}$ increases with the aggregate level of skilled human capital of a generation using the previous technology available in the economy. This level of technology is then function of the fraction of skilled people in the parent generation, as well as the level of productivity achieved in $t-1$. 


\subsection{The Dynamical System}

In order to characterize the dynamic development of the economy, we study the trajectory of three key variables over generations. The path of the economy is entirely described by the sequence $\left\{\Lambda_{t}, \theta_{t}, \alpha_{t}\right\}_{t=0}^{\infty}$, according to the evolution of the nonlinear first-order dynamic system of equations:

$$
\left\{\begin{array}{l}
\Lambda_{t}=\boldsymbol{\Lambda}\left(\theta_{t}, \alpha_{t}\right) \\
\theta_{t}=\boldsymbol{\theta}\left(\theta_{t-1}, \Lambda_{t-1}\right) \\
g_{t}=\boldsymbol{G}\left(\Lambda_{t-1}, \alpha_{t-1}\right)
\end{array},\right.
$$

The dynamic path of $\Lambda, \theta$ and $\alpha$ describes the joint evolution of the share of individual acquiring skilled education, gender equality and the relative productivity share (of each type of labor), given initial conditions $\Lambda_{0}, \theta_{0}$ and $\alpha_{0}$. The dynamic path does not depend on population size (no scale effect). We focus on the sub-system of equations, conditional on the value of the productivity share, $\alpha_{t}$, in order to illustrate the development dynamics. It results from the labor market equilibrium and the intergenerational externality on gender equality:

$$
\left\{\begin{array}{l}
\Lambda_{t}=\Lambda\left(\theta_{t}, \alpha_{t}\right) \\
\theta_{t}=\boldsymbol{\theta}\left(\theta_{t-1}, \Lambda_{t-1}\right)
\end{array}\right.
$$

The system delivers the dynamics of human capital formation and gender equality for a given relative productivity share $\alpha>0$. Any steady-state of the sub-system of equation is characterized by the intersection of $\boldsymbol{\Lambda}$ and $\boldsymbol{\theta}$.

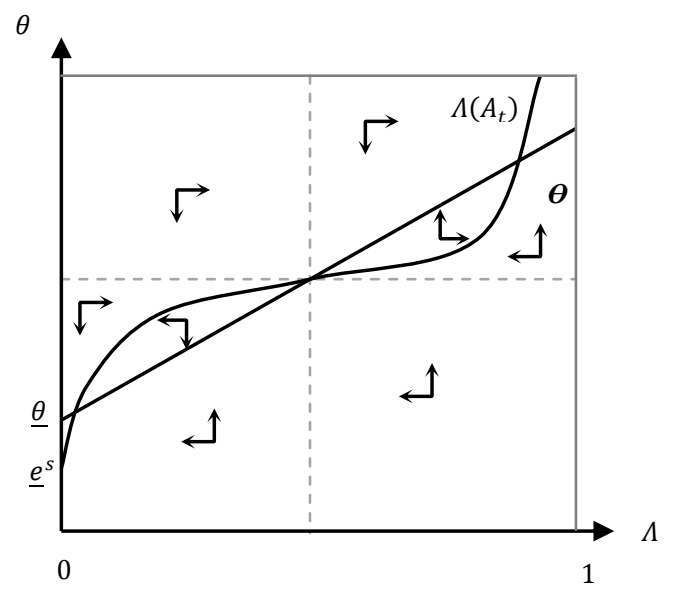


Given the non-linearity of $\boldsymbol{\Lambda}$ (S-shape trajectory), the dynamic sub-system is characterized by three different configurations that exhibit from one to three steady-state equilibria (see Figure 8 for the latter case). There are two stable and one unstable steady-state. The low steady state equilibrium is characterized by low gender equality and a small share of population acquiring skilled human capital. On the opposite, the high steady-state equilibrium is characterized by high gender equality and a relatively large fraction of population acquiring skilled human capital. Figure... illustrates the system under the existence of three steadystate equilibria. The state of the value of the productivity affects the relative returns from skilled human capital. A higher productivity, $A$, increases the returns to skilled human capital and the associated equilibrium fraction of individuals, $\Lambda$.

\subsection{The Global Dynamics of Development}

The evolution of the economy has to account for the evolution of all state variables. We focus here on the entire path of development: from stagnation to sustained growth. Then, how can economies move from the Malthusian trap of stagnation (with high fertility) to an era of sustained growth (with low fertility)?

We emphasize the existence of three main stages of development: the early stage of development ("Non-developed economy"), the transitory stage - toward the development ("Transitory economy") and the final stage of development ("Developed economy").

\subsubsection{Non-Developed Economy}

Non-developed economies are characterized by low gender equality $\underline{\theta}$ (close to its minimum) and low value of productivity $A_{0}$ (initial level). According to these conditions, investing in skilled human capital is costly for a large majority of the population. Thereby, the fraction of individuals acquiring skilled human capital $\Lambda$ is very low. The corresponding average fertility reflects those of individuals acquiring unskilled human capital (high fertility). 
Graphically, every intersection of the locus $\boldsymbol{\theta}$ and $\boldsymbol{\Lambda}$ represents an equilibrium. With initial low level of gender equality and low changes in technological progress, the dynamic system exhibits a unique globally stable steady-state equilibrium.

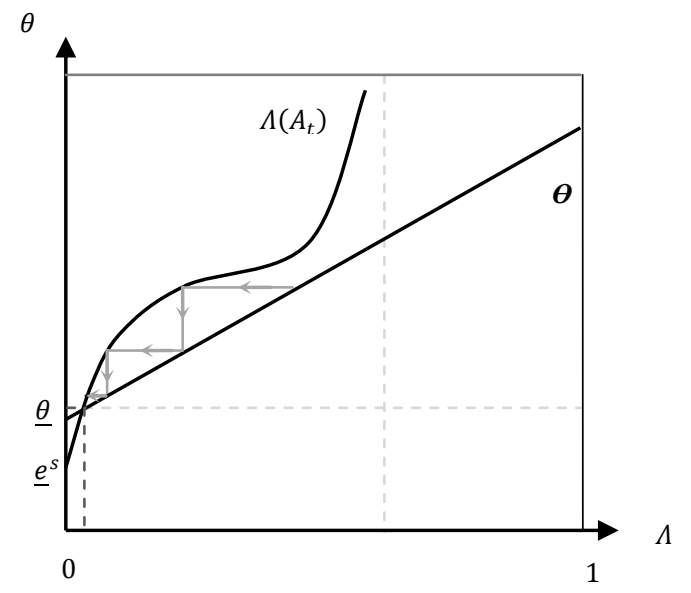

Figure 9. The Early Stage of the Process of DeVelopment

In a non-developed economy, gender equality and technological progress are close to their minimum, $\theta_{0} \simeq \underline{\theta}$ and $A_{0} \simeq 0$. The conditional system exhibits a unique steady state with few individuals acquiring skilled human capital $h^{s}$, $\Lambda_{0} \simeq 0$, and with large fertility rates.

$$
n \simeq \frac{\gamma}{\underline{\theta}(2+\gamma)} \frac{\left(1-e^{u}\right)}{\tau},
$$

At this stage of development, the economy is characterized by an extended phase with low living standards, low gender equality and large fertility.

\subsubsection{Transitory Economy}

As emphasized previously, Western countries experienced both an economic and a demographic transition. This transition account for a switchover from an environment characterized by low income per capita, low investments in education and high fertility to economy characterized by high living standards, a 
high share of the population investing in education and low number of children per women. Endogenous skill biased technological change leads to a monotonic increase in the importance of skilled human capital for production (by reinforcing the adoption of new ideas and technologies). Therefore, as generations pass, productivity growth makes investing in skilled education more profitable. However, as long as a certain level of gender equality is not reached, the process of human capital accumulation cannot start.

Graphically, productivity growth increases the convex part of the curve $\boldsymbol{\Lambda}$. The dynamic equilibrium moves along $\boldsymbol{\theta}$ triggering improvements in gender equality. Fertility remains high since the fraction of skilled individual is low. $\Lambda$ slowly shifts downwards and after sufficiently many generations $\boldsymbol{\Lambda}$ exhibits three intersections with $\boldsymbol{\theta}$, that is multiple equilibria: two locally stable steady-states and an interior unstable steady-state. In the absence of large shocks, the economy remains at the low steady-state equilibrium.

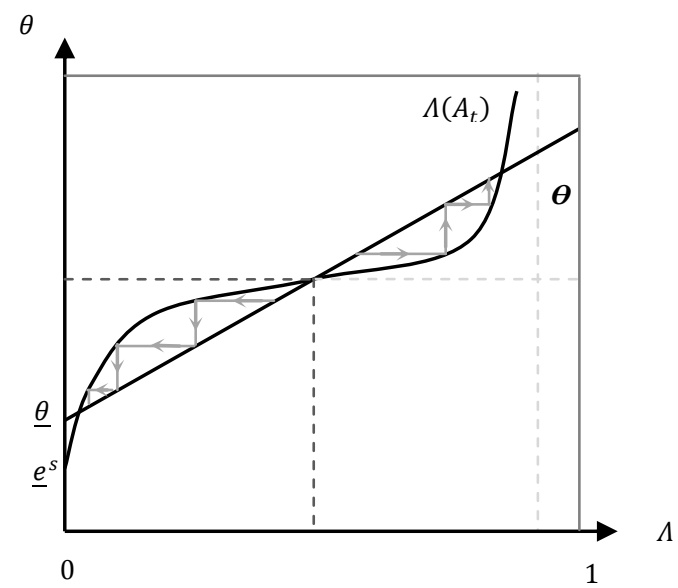

Figure 10. The Transitory Stage of the Process of Development

During this stage of development, the economy experiences increases in $\theta_{t}, \Lambda_{t}$, income per capita $\left(y_{t}\right)$ and technological level $A_{t}$. At this transitory stage of development, the economy is characterized by improvements in living standards, low gender equality and large fertility.

\subsubsection{Developed Economy}


In contrast to early stages of development, mature stages of development are characterized by advanced technology and high living standard. Gender equality is high, close to its maximum $\bar{\theta}$. Given these characteristics, investing in skilled human capital is much cheaper than in less advanced economy. As a consequence, the very large majority of the population acquires skilled human capital. Thereby, the fraction of individuals acquiring skilled human capital $\Lambda$ is very high. The corresponding average fertility reflects those of individuals acquiring unskilled human capital (low fertility).

In other words, the reach of a specific threshold in gender empowerment engages the process of human capital accumulation. Due to larger educational investments (in terms of time units), the female opportunity cost of having children increases and average fertility declines. Accordingly, households have fewer children but each of them is endowed with a higher quality of parental human capital - what de facto increases the ability of children to succeed in education and allow them to become in turn skilled individuals. From generations to generations, the fraction of skilled individuals increases and generates a positive feedback loop, impacting positively the rate of technological progress and the value of productivity. Ultimately, the economy experiences both a demographic and economic transition driven by improvements in gender equality.

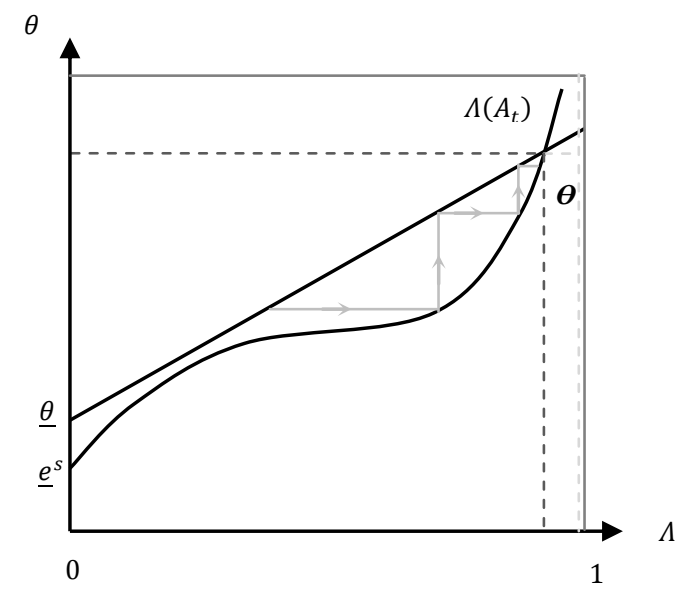

Figure 11. The Late Stage of The Process of Development

Graphically, as $\boldsymbol{\theta}$ and $\boldsymbol{\Lambda}$ shift downwards, the dynamic equilibrium exhibits a unique globally stable steady-state (a single intersection between the two curves). Once gender equality growth to a high level, $\bar{\theta}$, a substantially large fraction of 
the population decide to acquire skilled human capital. Therefore, it triggers to a period of rapid development (transition in living conditions) and the economy converges to the globally stable steady-state.

In a developed economy, with $A_{0} \simeq 1$, the conditional system exhibits a unique steady state where almost all the population acquire skilled human capital, $\Lambda \simeq 1$; gender equality is high $\theta \simeq \bar{\theta}$ and fertility rates are low,

$$
n \simeq \frac{\gamma}{\bar{\theta}(2+\gamma)} \frac{\left(1-e^{s}\right)}{\tau}
$$

At this mature stage of development, the economy is characterized by an extended phase with high living standards, high gender equality and low fertility.

The development process is therefore characterized by the evolution of economies from an era of stagnation to the demographic transition and the Modern Growth through the post-Malthusian Regime (as in Galor and Moav, 2002). Our model provides a new approach (complementary to that of Galor) with new mechanisms and new answers on how economies managed to escape the Malthusian trap to reach a state of sustained growth and to experience a demographic transition. In our model, the prime driving forces in this transition emerge from gender empowerment, as depicted by the phase diagrams (Figure 9 to 11$)$.

The rise in the rate of technological progress (through the emergence of new technologies) during the process of industrialization increased the demand for human capital and together raised the level of gender equality. Gender empowerment induces changes in gender relations. This gave greater opportunities for women to have access to higher education. Therefore, investing in education increases the opportunity cost of having children and implies for women to face a trade-off between education and fertility (professional versus family sphere). This is the so-called quantity-quality (Q-Q) trade-off ${ }^{24}$. This process ultimately triggers to the demographic transition.

\footnotetext{
24 Becker (1960) was the first to introduce the distinction between child quantity and child quality, followed by Becker and Lewis (1973) and Willis (1973).
} 


\section{Empirical Validations}

Empirical evidence of the relation linking the quantity and the quality of children is still scarce and does not bring yet clear conclusions. In this section, we estimate the long-run relationship between education and fertility behavior during the French demographic transition (in $19^{\text {th }}$ century), from a gendered perspective.

\subsection{A County-level Database for France in 1851}

We consider the relation between child quantity-quality trade-off for $19^{\text {th }}$ century France. We use regional data collected from diverse publications of the Service de la Statistique Générale de la France. Our dataset covers information about aggregated individual-level behavior for 86 French counties ${ }^{25}$ (départements). At the dawn of the nineteenth century, France was the largest European country with about 29.4 million inhabitants. The French Statistical Office publishes data from 1800. Nevertheless, it is from 1851 that published data rank population by age, gender, marital status and other essential information to study the evolution of fertility behavior and habits regarding education.

The major part of the dataset is constructed from General Censuses, Statistics of Primary Education, Population Movement and Industrial Statistics conducted in 1851 (1850 for Education, 1861 for Industrial Statistics). The rest of the data stems from diverse sources. A part of fertility data was available from the Princeton European Fertility Project (Coale and Watkins, 1986), while data on migration and life expectancy at birth come from Bonneuil (1997). A combined use of the various Censuses allows us to construct a dataset with detailed information on fertility, mortality, literacy rates, enrollment rates in primary schools for both boys and girls, employment in industry and agriculture by gender, level of urbanization and stage of industrialization ${ }^{26}$. In addition, we use data from French Censuses for the years 1821, 1835, 1861, 1881 and 1911 to get more demographic and socio-economic information necessary to carry out our analysis.

\footnotetext{
251851 France consist of current metropolitan French départements; Alpes-Maritimes, Savoie and Haute-Savoie removed.

26 To our knowledge, these data have not yet been used for micro-econometric analysis.
} 
TABLE 1

SUMMARY STATISTICS

\begin{tabular}{lcccc}
\hline \hline & Mean & Std. Dev. & Min & Max \\
\hline Crude birth rate & 26.95 & 3.597 & 18.717 & 34.275 \\
Boys enrollment rate & 0.544 & 0.211 & 0.188 & 1.059 \\
Girls enrollment rate & 0.356 & 0.259 & 0.003 & 0.997 \\
Female in industry & 0.036 & 0.070 & 0 & 0.552 \\
Female in agriculture & 0.615 & 0.179 & 0.037 & 1.054 \\
Male in industry & 0.057 & 0.081 & 0 & 0.636 \\
Male in agriculture & 0.737 & 0.171 & 0.046 & 1.135 \\
Urbanization & 0.059 & 0.083 & 0.007 & 0.736 \\
Population density (km $\left.{ }^{2}\right)$ & 1.011 & 3.166 & 0.219 & 29.907 \\
Life expectancy at age 0 & 38.792 & 6.115 & 25.8 & 50.8 \\
Share Protestants (1861) & 2.258 & 5.332 & 0.003 & 31.298 \\
Crude birth rate (1881) & 0.024 & 0.004 & 0.017 & 0.035 \\
Crude birth rate (1881-1911) & -0.245 & 0.092 & -0.405 & -0.002 \\
Marital fertility rate (1881) & 0.473 & 0.130 & 0.266 & 0.819 \\
Marital fertility rate (1881-1911) & -0.290 & 0.091 & -0.476 & 0 \\
Boys enrollment (1851-67) & 0.600 & 0.342 & -0.076 & 1.624 \\
Girls enrollment (1851-67) & 1.067 & 1.962 & 0.017 & 17.485 \\
Male literacy (1856-66) & 0.113 & 0.092 & -0.093 & 0.358 \\
Female literacy (1856-66) & 0.271 & 0.213 & -0.085 & 0.956 \\
\hline
\end{tabular}

Sources: Data for 86 counties from the French Censuses and demographic data for different years; See Appendix for details.

We use the crude birth rate as measure of fertility, which is defined as the number of births ${ }^{27}$ per 1000 inhabitants. We also use one measure of education for both boys and girls: the enrollment rates in public primary school in 1850, defined as the number of children attending school divided by the number of children aged 6-14.

Table 1 reports descriptive statistics of the variable used in our analysis. In 1816 , the literacy rate was about $51 \%$ for males and $30 \%$ for females on average. In $1851,54.5 \%$ of boys aged 6-14 were enrolled in public primary school, while the enrollment rate in public primary school for girls was $36 \%$. Yet, there is a strong heterogeneity in education across counties. It goes from a minimum of

\footnotetext{
27 As specify by BCW (2010), children aged 0-5 allows to capture surviving children (Galor 2005b).
} 
about $19 \%$ to a maximum of $105 \%^{28}$ for boys and from $0.3 \%$ to $99 \%$ for girls . These variations can be explained by several factors: diffusion of the official French language, difference in attitudes toward education between Catholics and Protestants (Becker and Woessmann, 2009), wave of spreading ideas coming from Prussia (Luther), insufficiency of educational resources deployed in rural areas (in terms of teachers, financial spending).

\subsection{Empirical Model}

We investigate the long-run effects of investments in human capital on fertility by estimating the impact of changes in literacy rates between 1856 and 1866 (as a measure of variations in human capital) on the decline in crude birth rate at the turn of the $20^{\text {th }}$ century in France.
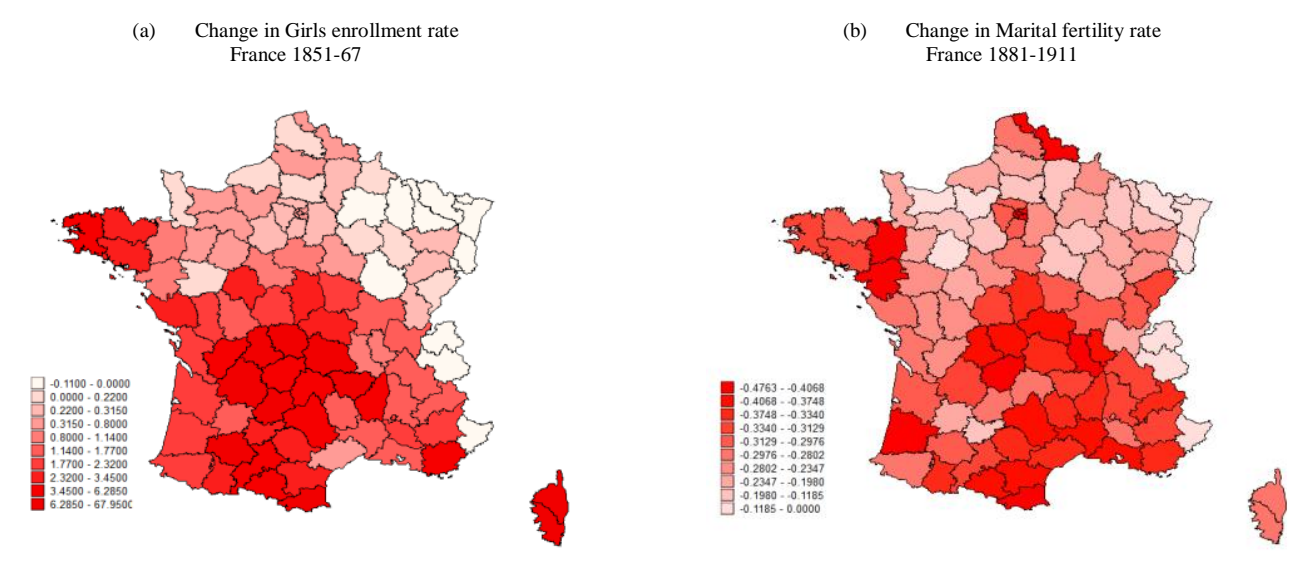

Figure 8. Geographical Distribution, France

The geographical distribution of percentage change in girls' enrollment rates between 1851 and 1867 is shown in Figure 8. The figure also displays the subsequent percentage change in marital fertility rate over the period 1881-1911. The more industrialized area (North-East part in France) shows lower variations in girls' enrollment rates over the period studied ${ }^{29}$. In contrast, the agricultural/rural - North-West, Middle and South France - tends to show higher

\footnotetext{
28 This is due to the possibility that children below 6 years old and above 14 years old might have been enrolled in public primary schools.

29 The enrollment rates in North-East France (in more urbanized counties) increased at a higher pace before the period studied. This is why the percentage change is lower is this part than in the rest of the country.
} 
percentage changes in girls' schooling. Comparatively, the highest and the lowest percentage change in marital fertility over the period 1881-1911 are located in the same areas where girls' enrollment rates are respectively higher and lower.

We use equation 1 to test the hypothesis that human capital accumulation and especially female human capital was a key ingredient allowing for the demographic transition. We choose literacy ${ }^{30}$ rates as a measure of the value of a region's human capital. Therefore, we estimate the impact of both the percentage change in males' and females' literacy rates between 1856 and 1866 on the fertility decline over the period 1881-1911 during the French demographic transition:

$$
\text { fertility }_{i, 1881-1911}=\alpha_{1} \text { education }_{i, 1856-66}^{j}+\boldsymbol{X}_{i 1} \delta_{1}+e_{i 1}
$$

where the subscript $j$ refers to the gender of individuals (either male or female) and $i$ refers to the counties. The percentage change in the crude birth rate (1881$1911)$ is the dependant variable; and is function of the percentage change in literacy rate (1856-66). The coefficient $\alpha_{1}$ is our parameters of interest. $\boldsymbol{X}_{1}$ is the vector of control variables (see in appendix for a description of the variables). We estimate equation (1) using ordinary least squares (OLS).

We introduce various specifications to study how males and females endowments in human capital affect their future fertility. The covariates used in the regression analysis are: $(i)$ a proxy for the level of industrialization specified as the share of people employed in manufacturing by gender, (ii) the share of people making their living of agriculture by gender, (iii) the urbanization, (iv) population density, ( $v)$ the share of Protestants, (vi) life expectancy at age $0,(v i i)$, (viii) the crude birth rate in 1851, (ix) the crude birth rate in 1881.

\subsection{Results}

Table $2 \mathrm{a}$ and $2 \mathrm{~b}$ report OLS estimates of equation 1 where variations in crude birth rate are respectively function of variations in males' literacy rates and females' literacy rates.

\footnotetext{
30 Literacy refers to the ability to read and to write. Literate people can be more easily trained and enjoy better health and employment opportunities than illiterate people.
} 
TABLE 2A

THE LONG-RUN EFFECT OF MALES HuMAN CAPITAL ON THE FERTILITY TRANSITION

\begin{tabular}{|c|c|c|c|c|}
\hline \multirow{2}{*}{ Dependent variable } & \multicolumn{4}{|c|}{ Crude birth rate (\% change 1881-1911) } \\
\hline & (1) & (2) & (3) & (4) \\
\hline $\begin{array}{l}\text { Male literacy } \\
\text { (\% change 1856-66) }\end{array}$ & $\begin{array}{l}-0.123 \\
(0.083)\end{array}$ & $\begin{array}{l}-0.162 \\
(0.083)\end{array}$ & $\begin{array}{l}-0.152 \\
(0.084)\end{array}$ & $\begin{array}{l}-0.119 \\
(0.084)\end{array}$ \\
\hline Crude birth rate & $\begin{array}{l}-0.014^{* * *} \\
(0.003)\end{array}$ & $\begin{array}{l}-0.013^{* * *} \\
(0.002)\end{array}$ & $\begin{array}{l}-0.014^{* * *} \\
(0.003)\end{array}$ & $\begin{array}{l}-0.019^{* * *} \\
(0.004)\end{array}$ \\
\hline Male in industry & $\begin{array}{l}0.070 \\
(0.075)\end{array}$ & $\begin{array}{l}0.070 \\
(0.080)\end{array}$ & $\begin{array}{l}0.076 \\
(0.081)\end{array}$ & $\begin{array}{l}0.029 \\
(0.095)\end{array}$ \\
\hline Male in agriculture & $\begin{array}{l}-0.187^{* *} \\
(0.067)\end{array}$ & $\begin{array}{l}-0.170^{*} \\
(0.067)\end{array}$ & $\begin{array}{l}-0.171^{*} \\
(0.069)\end{array}$ & $\begin{array}{l}-0.186^{* *} \\
(0.065)\end{array}$ \\
\hline Urbanization & $\begin{array}{l}-1.013 \\
(0.636)\end{array}$ & $\begin{array}{l}-0.873 \\
(0.615)\end{array}$ & $\begin{array}{l}-0.805 \\
(0.586)\end{array}$ & $\begin{array}{l}-0.763 \\
(0.605)\end{array}$ \\
\hline Population density & $\begin{array}{l}0.017 \\
(0.014)\end{array}$ & $\begin{array}{l}0.014 \\
(0.013)\end{array}$ & $\begin{array}{l}0.012 \\
(0.012)\end{array}$ & $\begin{array}{l}0.011 \\
(0.013)\end{array}$ \\
\hline Share protestants & & $\begin{array}{l}-0.003^{* *} \\
(0.001)\end{array}$ & $\begin{array}{l}-0.003^{* *} \\
(0.001)\end{array}$ & $\begin{array}{l}-0.004^{*} \\
(0.002)\end{array}$ \\
\hline Life expectancy: age 0 & & & $\begin{array}{l}-0.001 \\
(0.002)\end{array}$ & $\begin{array}{l}-0.000 \\
(0.002)\end{array}$ \\
\hline Crude birth rate (1881) & & & & $\begin{array}{l}6.279 \\
(3.961)\end{array}$ \\
\hline Constant & $\begin{array}{l}0.294^{* * *} \\
(0.065)\end{array}$ & $\begin{array}{l}0.273^{* * *} \\
(0.065)\end{array}$ & $\begin{array}{l}0.321^{*} \\
(0.129)\end{array}$ & $\begin{array}{l}0.286^{*} \\
(0.130)\end{array}$ \\
\hline $\mathrm{N}$ & 83 & 83 & 83 & 83 \\
\hline$R^{2}$ & 0.517 & 0.541 & 0.542 & 0.564 \\
\hline$F$ & 28.583 & 26.007 & 23.288 & 20.878 \\
\hline
\end{tabular}

Notes: OLS regressions. Dependent variable: \% change crude birth rate. Robust standard errors in parentheses $-^{*} p<0.05,{ }^{* *} p<0.01,{ }^{* * *} p<0.001$. Male literacy rate is number of males able to read and to write over total number of males.

Source: County-level data from French censuses.

We control for socio-economic factors adding successively control variables for employment opportunities and urbanization (column 1), religion (column 2), life expectancy (column 3) and crude birth rate in $1881^{31}$ (column 4). The estimates show that counties where the percentage variation of investment in human capital is higher between 1856-66 experience higher variations in fertility on the period 1881-191 - during the French demographic transition.

\footnotetext{
${ }^{31}$ In order to test for robustness, we add the initial level crude birth rate in 1881.
} 
TABLE 2B

THE LONG-RUN EFFECT OF Females Human CAPITAL ON THE FerTILITY TRANSITION

\begin{tabular}{|c|c|c|c|c|}
\hline \multirow{2}{*}{ Dependent variable } & \multicolumn{4}{|c|}{ Crude birth rate (\% change $1881-1911$ ) } \\
\hline & (1) & (2) & (3) & (4) \\
\hline $\begin{array}{l}\text { Female literacy } \\
\text { (\% change 1856-66) }\end{array}$ & $\begin{array}{l}-0.158^{* * *} \\
(0.033)\end{array}$ & $\begin{array}{l}-0.156^{* * *} \\
(0.033)\end{array}$ & $\begin{array}{l}-0.155^{* * *} \\
(0.036)\end{array}$ & $\begin{array}{l}-0.148^{* * *} \\
(0.037)\end{array}$ \\
\hline Crude birth rate & $\begin{array}{l}-0.013^{* * *} \\
(0.002)\end{array}$ & $\begin{array}{l}-0.013^{* * *} \\
(0.002)\end{array}$ & $\begin{array}{l}-0.013^{* * *} \\
(0.003)\end{array}$ & $\begin{array}{l}-0.017^{* * *} \\
(0.003)\end{array}$ \\
\hline Female in industry & $\begin{array}{l}-0.003 \\
(0.124)\end{array}$ & $\begin{array}{l}0.005 \\
(0.125)\end{array}$ & $\begin{array}{l}0.006 \\
(0.129)\end{array}$ & $\begin{array}{l}-0.027 \\
(0.133)\end{array}$ \\
\hline Female in agriculture & $\begin{array}{l}-0.144^{* *} \\
(0.045)\end{array}$ & $\begin{array}{l}-0.141^{* *} \\
(0.045)\end{array}$ & $\begin{array}{l}-0.142^{* *} \\
(0.048)\end{array}$ & $\begin{array}{l}-0.146^{* *} \\
(0.047)\end{array}$ \\
\hline Urbanization & $\begin{array}{l}-0.925 \\
(0.526)\end{array}$ & $\begin{array}{l}-0.798 \\
(0.500)\end{array}$ & $\begin{array}{l}-0.783 \\
(0.494)\end{array}$ & $\begin{array}{l}-0.729 \\
(0.528)\end{array}$ \\
\hline Population density & $\begin{array}{l}0.016 \\
(0.012)\end{array}$ & $\begin{array}{l}0.013 \\
(0.011)\end{array}$ & $\begin{array}{l}0.012 \\
(0.011)\end{array}$ & $\begin{array}{l}0.011 \\
(0.012)\end{array}$ \\
\hline Share protestants & & $\begin{array}{l}-0.003^{* * *} \\
(0.001)\end{array}$ & $\begin{array}{l}-0.003^{* *} \\
(0.001)\end{array}$ & $\begin{array}{l}-0.004^{* *} \\
(0.001)\end{array}$ \\
\hline Life expectancy: age 0 & & & $\begin{array}{l}-0.000 \\
(0.001)\end{array}$ & $\begin{array}{l}0.000 \\
(0.001)\end{array}$ \\
\hline Crude birth rate (1881) & & & & $\begin{array}{l}5.327 \\
(3.284)\end{array}$ \\
\hline Constant & $\begin{array}{l}0.249^{* * *} \\
(0.057)\end{array}$ & $\begin{array}{l}0.241^{* * *} \\
(0.057)\end{array}$ & $\begin{array}{l}0.255^{*} \\
(0.121)\end{array}$ & $\begin{array}{l}0.218 \\
(0.121)\end{array}$ \\
\hline $\mathrm{N}$ & 83 & 83 & 83 & 83 \\
\hline$R^{2}$ & 0.606 & 0.628 & 0.628 & 0.644 \\
\hline$F$ & 44.057 & 43.032 & 37.989 & 34.719 \\
\hline
\end{tabular}

Notes: OLS regressions. Dependent variable: \% change crude birth rate. Robust standard errors in parentheses $-^{*} p<0.05,{ }^{* *} p<0.01,{ }^{* * *} p<0.001$. Female literacy rate is number of females able to read and to write over total number of females.

Source: County-level data from French censuses.

In particular, we find very interesting results in terms of gendered impact. Investigating the effect of changes in males' literacy rates on the fertility transition; we observe that, no matter the specification, the negative correlation remains always non-significant (Table 2a). In contrast, the estimates are particularly robust and significant (probability of error inferior to 0.001 ) when percentage change in fertility is function of females' literacy rates (Table 2b). The coefficients indicate that the fertility transition is stronger in areas where 
individuals are more oriented toward agriculture ${ }^{32}$. The transition is also more important in counties with a higher share of Protestants (see Table $2 \mathrm{a}$ and $2 \mathrm{~b}-$ Column 2, 3, 4). More specifically, in the richest specification (column 4 - Table 2b) an increase in the variation of females literacy rates by $10 \%$ is associated with a negative variation in fertility by about 1.5 children.

In terms of explanatory power, the richest model (column 4 - Table 2b) accounts for more than $64 \%$ of the variations in crude birth rate across counties. Therefore, our results are coherent with the interpretation of the unified growth theory (Galor, 2005b; Galor and Moav, 2002) and especially with Diebolt and Perrin (2012). According to the latter, female empowerment as well as technological progress increased returns to education for girls because of complementarities between technological changes and human capital. As a consequence, girls could invest more in their own education and limited their fertility (due to higher opportunity costs of having children). In other words, girls with higher endowments in human capital have fewer children. As a consequence, as far as females human capital increases, fertility declines and ultimately lead to the fertility transition.

\subsection{Final Remarks}

In agreement with the unified growth model presented above, the preference for child quality rather than child quantity as a result of improvement in female human capital is likely to be a key ingredient allowing economies to experience a transition from a very long period of stagnation to a stage of sustained growth. Using a dataset of 86 county-level observations built up from Population and Education Censuses conducted in 1851, we document the existence of a child quantity-quality trade-off for France. We find the existence of a negative correlation between education and fertility during the demographic transition. More precisely, we show that variations in female literacy rates (1856-66) have a robust and significant impact on fertility transition between 1881 and 1911: counties with higher improvements in female literacy rates between 1856 and 1866 show a stronger fertility decline at the turn of the $19^{\text {th }}$ century.

Therefore, our estimates suggest that females with higher levels of human capital have stronger preferences for a lower number of children.

\footnotetext{
32 Note that agricultural areas are also those where education levels were historically the lowest and where fertility was the most important (in comparison with industrialized areas).
} 


\section{Conclusion}

This paper shed lights on the importance of the role played by female empowerment (changes in gender relations) on the development process. We argue that gender empowerment have been necessary to allow economies to move from stagnation to sustained growth. Our intuition is that the transition from a "Patriarchal" organization of the society (male-breadwinner model), characterized by a sexual division of labor with a desire for households to maximize both their income and the number of children, toward a "Modern" organization of the society (dual-earnings model), characterized by a better distribution of duties within the household, where both men and women work on the labor market, is at the heart of both the process of human capital accumulation and the demographic transition that occurred during the process of development in Western countries.

More specifically, we develop a unified cliometric growth model that encompasses the interplay between income, gender equality and fertility. Our model suggests that gender empowerment is a crucial factor of both demographic and economic transition. In particular, the theory points out that the acceleration of skill-biased technological progress generates a positive externality on the level of gender equality. Both wages and gender equality are key variables in the education decision process of individuals. More specifically, higher gender equality reinforces individuals' incentives to acquire skilled human capital. In turn, female choices in terms of time and quality of educational investments increase their endowment in human capital and impact positively the fraction of the subsequent generation of individuals acquiring skilled education. In other words, improvements in technological progress, gender equality and skilled human capital reinforce each other. Ultimately, the presence of a sufficiently high fraction of skilled individuals in the population yields to sustained economic growth.

In the early stage of development, the low rate of technological progress does not provide any incentive to invest in skilled education. Therefore, the fraction of skilled individuals is low and the economy remains trapped in a Malthusian steady-state equilibrium, with low education, low living standard and low gender equality. Technological progress is assumed to increase monotonically from 
generation to generation. Thereby, as technological progress grows, we observe a qualitative change, and the subsequent income effect triggers (temporarily) to higher fertility rates. After sufficiently many generations, increases in the returns from investments in skilled education (productivity growth) - driven by the rise in technological progress - makes investing in skilled education more profitable so that gender equality improves. The dynamical system of skilled human capital and gender equality is therefore characterized by multiple steady-state equilibria. Since gender equality becomes high enough, a substantially larger fraction of individuals acquires skilled human capital what triggers to rapid developments and reinforces gender equality. Due to larger educational investments (in terms of time units), female opportunity cost of having children increases and average fertility declines: the demographic transition occurs along with the process of human capital accumulation. Ultimately, in later stage of development, gender equality and the fraction of skilled individuals converge towards their maximum. Thereby, the economy is characterized by a Modern Growth steady-state equilibrium, where living standards are high, gender equality is high and fertility is low.

An empirical verification of the effect of female education on fertility transition based on past data is conducted in section 5 - in order to investigate the relevance of our theory. Using a dataset of 86 county-level observations built up from Population and Education Censuses in the $19^{\text {th }}$ century, we document the existence of a quantity-quality trade-off for France. In accordance with our theory, we find the existence of a negative correlation between female education and fertility during the demographic transition. One next step is here to explain why the demographic transition occurs first in France.

More generally our research had the ambition to be an original illustration of the main achievement of cliometric research in the recent years, i.e. to slowly but surely establish a solid set of economic analyses of historical evolution by means of measurement and theory. A future objective is to consolidate this research agenda, i.e. to contribute to close the gap between theoretical growth models and economic history and, in so doing, encouraging economists to examine more systematically these theories grounded upon history and nevertheless aiming at determining general laws. This middle road might open the door to a better economic theory, enabling economists to interpret current economic issues in the light of the past and to understand more deeply the historical working and path dependence of the socio-economic processes (Diebolt, 2012). 


\section{REFERENCES}

Angrist J., V. Lavy, A. Schlosser (2010), "Multiple Experiments for the Causal Link between the Quantity and Quality of Children", Journal of Labor Economics, University of Chicago Press, 28, p. 773-824.

Azariadis C., A. Drazen (1990), "Demographic Transition in a Dual Economy”, Mimeo, University of Pennsylvania.

Barro R.J. (1997), "Determinants of Economic Growth: A Cross-Country Empirical Study”. Development Discussion Paper 579, Harvard Institute for International Development.

Barro R.J., G.S. Becker (1989), "Fertility Choice in a Model of Economic Growth". Econometrica, 57, p. 481-501.

Becker G.S. (1960), “An Economic Analysis of Fertility”, In: Gary S. Becker (ed.), Demographic and Economic Change in Developed Countries, p. 209240. Princeton, NJ: Princeton University Press.

Becker G.S. (1965), "A Theory of the Allocation of Time", The Economic Journal, 75, p. 493-517.

Becker G.S. (1981), A Treatise on the Family. Harvard University Press.

Becker G.S., R.J. Barro (1988), "A reformulation of the economic theory of fertility". Quarterly Journal of Economics, 103, p. 1-26.

Becker G.S., H.G. Lewis (1973), “On the Interaction between the Quantity and Quality of Children”, Journal of Political Economy, 81, p. 279-288.

Becker G.S., K.M. Murphy, R. Tamura (1990), "Human capital, fertility, and economic growth", Journal of Political Economy, 98, p. 12-37.

Becker S.O., F. Cinnirella, L. Woessmann (2010), “The Trade-off between Fertility and Education: Evidence from before the Demographic Transition”, Journal of Economic Growth, 15, p. 177-204. 
Becker S.O., F. Cinnirella, L. Woessmann (2012), "The effect of investment in children's education on fertility in 1816 Prussia", Cliometrica, 6, p. 29-44.

Becker S.O., L. Woessmann (2009), "Was Weber Wrong? A Human Capital Theory of Protestant Economic History", Quarterly Journal of Economics, 124, p. 531-596.

Birdsall N. (1988), Economic approaches to population growth. The Handbook of Development Economics. North Holland.

Black S.E., P.J. Devereux, K.G. Salvanes (2005), “The More the Merrier? The Effect of Family Size and Birth Order on Children's Education”, Quarterly Journal of Economics, 120, p. 669-700.

Bleakley H., F. Lange (2009), "Chronic Disease Burden and the Interaction of Education, Fertility, and Growth", Review of Economics and Statistics, 91, p. 52-65.

Blum A., J. Houdaille (1985), "L'alphabétisation aux XVIIIe et XIXe siècles : l'illusion parisienne ?", Population, 40, p. 944-951.

Bonneuil N. (1997), Transformation of the French Demographic Landscape 1806-1906. Oxford: Clarendon Press.

Breierova L., E. Duflo (2004), "The Impact of Education on Fertility and Child Mortality: Do Fathers Really Matter Less Than Mothers?”, NBER Working Paper 10513, Cambridge, MA: National Bureau of Economic Research.

Butz W.P., M.P. Ward (1979), “The Emergence of Countercyclical United States Fertility", American Economic Review, 69, p. 318-328.

Cáceres-Delpiano J. (2006), “The Impacts of Family Size on Investments in Child Quality", Journal of Human Resources, 41, p. 738-754.

Caldwell J.C. (1980), "Mass Education as a Determinant of the Timing of Fertility Decline", Population and Development Review, 6, p. 225-255. 
Cervellati M., U. Sunde (2005), "Human Capital Formation, Life Expectancy and the Process of Development", American Economic Review, 95, p. 16531672 .

Cervellati M., U. Sunde (2007), "Human Capital Formation, Mortality and Fertility: A Unified Theory of the Economic and Demographic Transition”, IZA Discussion Paper, No 2905, July.

Chesnais J.C. (1992), The Demographic Transition: Stages, Patterns, and Economic Implications, Oxford University Press, September.

Coale A.J., S.C. Watkins (1986), The Decline of Fertility in Europe. Princeton, NJ: Princeton University Press.

Commaille J. (1992), Les stratégies des femmes. Travail, famille et politique, Paris, La Découverte.

Currie J., E. Moretti (2003), "Mother's Education and the Intergenerational Transmission of Human Capital; Evidence from College Openings", Quarterly Journal of Economics, 118, p. 1495-1532.

Dahan M., D. Tsiddon (1998), "Demographic transition, income distribution, and economic growth", Journal of Economic Growth, 3, p. 29-52.

David P. (2007), "Path dependence: a foundational concept for historical social science", Cliometrica, 1, p. 91-114.

Davis K., Blake J. (1956), "Social Structure and Fertility: An Analytical Framework", Economic Development and Cultural Change, 4, p. 211-235.

De Moor T., J.L. Van Zanden (2009), "Girl power: the European marriage pattern and labour markets in the North Sea Region in the late medieval and early modern period", Economic History Review, Economic History Society, 63, p. 1-33.

Deville J.-C. (1979), “La fécondité serait-elle héréditaire?”, Économie et Statistique, 116, p. 3-11.

Diebolt C. (2012), “The Cliometric Voice”, AFC Working Paper, 12, p. 1-9. 
Diebolt C., M. Monteils (2000), "The new growth theories. A survey of theoretical and empirical contributions", Historical Social Research, 25, p. 3-22.

Diebolt C., F. Perrin (2012), “Gender Equality, Human Capital and Fertility: A Unified Growth Model”, $8^{\text {th }}$ BETA Workshop, May 11-12, Strasbourg.

Diebolt, C., F. Perrin (2012), “A Unified Cliometric Growth Model of Female Empowerment", Unpublished Manuscript, University of Strasbourg.

Doepke M. (2004), “Accounting for Fertility Decline during the Transition to Growth", Journal of Economic Growth, 9, p. 347-383.

Doepke M. (2005), “Child Mortality and Fertility Decline: Does the BarroBecker Model Fit the Facts?", Journal of Population Economics, 18, p. 337-366.

Dollar D., R. Gatti (1999), “Gender inequality, income and growth: are good times good for women?", Policy Research Report on Gender and Development Working Paper Series, $\mathrm{n}^{\circ}$ 1, The World Bank, Washington, DC.

Dribe M. (2009), "Demand and supply factors in the fertility transition: a countylevel analysis of age-specific marital fertility in Sweden, 1880-1930", European Review of Economic History, 13, p. 65-94.

Ehrlich I., F.T. Lui (1991), "Inter-generational trade, longevity, and economic growth”, Journal of Political Economy, 99, p. 1129-1059.

Ehrlich I., F.T. Lui (1997), "The problem of population and growth : A review of the literature from Malthus to contermporary models of endogenous population and endogenous growth", Journal of Economic Dynamics and Control, 21, p. 205-242.

Fernihough A. (2011), "Human Capital and the Quantity-Quality Trade-Off during the Demographic Transition: New Evidence from Ireland", Working Papers 201113, School Of Economics, University College Dublin. 
Fine A. (1988), “Enfants et normes familiales”, In: J. Dupâquier (eds.), Histoire de la Population Française, p. 436.

Galloway P.R., E.A. Hammel, R.D. Lee (1994), "Fertility Decline in Prussia, 1875-1910: A Pooled Cross-Section Time Series Analysis”, Population Studies, 48, p. 135-158.

Galor O. (2005a), "From Stagnation to Growth: Unified Growth Theory", In: Philippe Aghion, Steven N. Durlauf (eds.), Handbook of Economic Growth, Vol. 1A, p. 171-293. Amsterdam: Elsevier.

Galor O. (2005b), "The Demographic Transition and the Emergence of Sustained Economic Growth", Journal of the European Economic Association, 3, p. 494-504.

Galor O. (2012), "The Demographic Transition: Causes and Consequences", Cliometrica, 6, p. 494-504.

Galor O., O. Moav (2002), "Natural Selection and the Origin of Economic Growth”, Quarterly Journal of Economics, 117, p. 1133-1191.

Galor O., D.N. Weil (1996), “The gender gap, fertility, and growth”, American Economic Review, 86, p. 374-387.

Galor O., D.N. Weil (1999), “From Malthusian Stagnation to Modern Growth". American Economic Review, 89, p. 150-154.

Galor O., D.N. Weil (2000), "Population, Technology, and Growth: From Malthusian Stagnation to the Demographic Transition and Beyond", American Economic Review, 90, p. 806-828.

Goldin C. (1990), Understanding the gender gap: An economic history of American women. New York: Oxford University Press.

Goldin C. (1994), "The U-Shaped Female Labor Force Function in Economic Development and Economic History", National Bureau of Economic Research (Cambridge, MA), Working Paper No. 4707, April. 
Goldin C. (2004), "From the Valley to the Summit: The Quiet Revolution that Transformed Women's Work", National Bureau of Economic Research, Working Paper No. 10335, March.

Goldin C. (2006), “The Quiet Revolution that Transformed Women's Employment, Education, and Family", National Bureau of Economic Research, Working Paper No. 11953, January.

Goldin C., L. Katz (2001), “On the Pill: Changing the Course of Women's Education”, Milken Institute Review, 3, p 12-21.

Greenwood J., A. Seshadri (2002), “The U.S. Demographic Transition”, American Economic Review, Papers and Proceedings, 92, p. 153-159.

Greenwood J., A. Seshadri, M. Yorukoglu (2005), "Engines of liberation”, Review of Economic Studies, 72, p. 109-133.

Hajnal J. (1965), "European Marriage patterns in Perspective", in: Glass, D.V. and Eversley.

Hansen G.D., E.C. Prescott (2002), "Malthus to Solow", American Economic Review, 92, p. 1205-1217.

Hanushek E.A. (1992), “The Trade-Off between Child Quantity and Quality”, Journal of Political Economy, 100, p. 84-117.

Henri L., J. Houdaille (1978), "Célibat et âge au mariage aux XVIIIe et XIXe siècles en France : I. Célibat définitif”, Population, 33, p. 43-84.

Henri L., J. Houdaille (1979), “Célibat et âge au mariage aux XVIIIe et XIXe siècles en France : II. Age au premier mariage”, Population, 34, p. 403442.

Iyigun M.F. (2000), “Timing of childbearing and economic growth", Journal of Development Economics, 61, p. 255-269.

Iyigun M.F., R.P. Walsh (2007), “Endogenous Gender Power, Household Labor Supply and the Demographic Transition", Journal of Development Economics, Vol. 82, p. 138-155. 
Jones C.I. (2001), "Was an industrial revolution inevitable? Economic growth over the very long run", Advances in Macroeconomics, 1, p. 1-43.

Klasen S. (2002), "Low schooling for girls, slower growth for all? Cross-country evidence on the effect of gender inequality in education on economic development", The World Bank Economic Review, 16, p. 345-373.

Klemp M., J. Weisdorf (2011), “The Child Quantity-Quality Trade-Off during the Industrial Revolution in England”, Discussion Papers 11-16, University of Copenhagen, Department of Economics.

Klemp M. (2012), "Price, Wages and Fertility in Pre-Industrial England", Cliometrica, 6, p. 63-78.

Kuznets S. (1967), "Population and Economic Growth", Proceedings of the American Philosophical Society, 111, p. 170-193. Reprinted 1997 in J.L. Simon (ed.), The Economics of Population : Key Modern Writings, 1, London : Edward Elgar.

Langevin A. (1984), "Régulation sociale du temps fertile des femmes", Le sexe du travail, p. 97-112.

Leibenstein H. (1957), Economic backwardness and economic growth, New York: Wiley; London: Chapman and Hall.

Li H., J. Zhang, Y. Zhu (2008), “The Quantity-Quality Trade-Off of Children in a Developing Country: Identification Using Chinese Twins", Demography, 45 , p. 223-243.

Lucas R.E. (1988), “On the mechanics of economic development”. Journal of Monetary Economics, 22, p. 3-42.

Lucas R.E. (2002), Lectures on Economic Growth. Cambridge, MA: Harvard University Press.

Maddison A. (2001), The World Economy: A Millennial Perspective. Paris: OECD. 
Maddison A. (2003), The World Economy: Historical Statistics, Paris, OECD Development Center Studies.

Malthus R.T. (1798), Essai sur le principe de population. Traduction de E. Vilquin, 1980, INED et PUF, Paris.

Mammen K., C. Paxson (2000), “Women's Work and Economic Development”, The Journal of Economic Perspectives, 14, p. 141-164.

Maruani M. (1996), «L'emploi féminin à l'ombre du chômage », Actes de la recherche en sciences sociales, 115, p. 48-57.

Mincer, J. (1962), Labor Force Participation of Married Women: A Study of Labor Supply. Aspects of labor economics, H. Gregg Lewis (eds). Princeton: Princeton University Press, p. 63-97.

Nerlove, M. (1974), “Toward a new theory of population and economic growth", Journal of Political Economics, 84, p. S200-S216.

Osili U.O., B.T. Long (2008), "Does Female Schooling Reduce Fertility? Evidence from Nigeria", Journal of Development Economics, 87, p. 57-75.

Pailhé A., A. Solaz (2007), "Inflexions des trajectoires professionnelles des hommes et des femmes après la naissance d'enfants", Recherche et Prévision, 90, p. 5-27.

Qian, N. (2009), "Quantity-Quality and the One Child Policy: The Only-Child Disadvantage in School Enrollment in Rural China", NBER Working Paper 14973. Cambridge, MA: National Bureau of Economic Research.

Razin A., U. Ben-Zion (1975), “An Intergenerational Model of Population Growth", American Economic Review, 65, p. 923-933.

Rodgers J. L., K. Hughes, H.-P. Kohler, K. Christensen, D. Doughty, D.C. Rowe, W.B. Miller (2001), “Genetic Influence Helps Explain Variation in Human Fertility: Evidence From Recent Behavioral and Molecular Genetic Studies", Current Directions in Psychological Science, 10, p. 184-188. 
Romer P. (1986), “Increasing returns and long-run growth", Journal of Political Economy, 94, p. S1002-S1037.

Romer P. (1990), "Endogenous Technological Change", The Journal of Political Economy, 98, p. S71-S102.

Rosenzweig M.R., K.I. Wolpin (1980), “Testing the Quantity-Quality Fertility Model: The Use of Twins as a Natural Experiment", Econometrica, 48, p. 227-240.

Rosenzweig M.R., J. Zhang (2009), "Do Population Control Policies Induce More Human Capital Investment? Twins, Birthweight, and China's 'One Child' Policy", Review of Economic Studies, 76, 3, p. 1149-174.

Schultz P.T. (1986), "The Value and Allocation of Time in High-Income Countries: Implications for Fertility". Population and Development Review, 12, p. 87-108.

Schultz T.P. (1994), "Human Capital, Family Planning and Their Effects on Population Control”, American Economic Review, 83, p. 255-260.

Schultz T.P. (1995), "Investments in schooling and health of women and men: quantities and returns", in T.P. Schultz (ed.), Investment in Women's Human Capital, University of Chicago Press.

Schultz T.P. (2008), "Population Policies, Fertility, Women's Human Capital, and Child Quality", In: T. Paul Schultz, John Strauss (eds.), Handbook of Development Economics, vol. 4, pp. 3249-3303. Amsterdam: Elsevier.

Scott J.W., L. Tilly (1987), Women, Work and Family, Routledge.

Solow R.M. (1956), "A contribution to the theory of economic growth", Quarterly Journal of Economics, 70, p. 65-94.

Srinivasan T.N. (1988), "Population growth and economic development", Journal of Policy Modeling, 10, p. 7-28.

Strulik H., J. Weisdorf (2008), "Population, Food, and Knowledge: A Simple Unified Growth Theory", Journal of Economic Growth, 13, p. 195-216. 
Tamura R. (1994), "Fertility, human capital and the wealth of families", Economic Theory, 4, p. 593-603.

Tamura R. (1996), "From decay to growth: A demographic transition to economic growth", Journal of Economic Dynamics and Control, 20, p. 1237-1261.

Van de Walle E. (1986), "La fécondité française au XIXe siècle", Communications, 44, p. 35-45.

Willis R.J. (1973), “A New Approach to the Economic Theory of Fertility Behavior", Journal of Political Economy, 81, p. 14-64.

Wooldridge J.M. (2002), Econometric Analysis of Cross Section and Panel Data. Cambridge, MA: MIT Press. 


\section{APPENDIX}

\section{Section 1. The Stylized Facts}

Data used for Figure 1 to 3 is for a set of 114 countries, referenced below, in 2006.

\begin{tabular}{|c|c|c|c|c|c|c|c|}
\hline $\begin{array}{l}\text { Eastern } \\
\text { Europe }\end{array}$ & Asia & Europe & $\begin{array}{c}\text { Latin } \\
\text { America } \\
\text { and } \\
\text { Carribean }\end{array}$ & $\begin{array}{l}\text { Middle- } \\
\text { East } \\
\text { and Arab } \\
\text { World }\end{array}$ & $\begin{array}{c}\text { North } \\
\text { America }\end{array}$ & Oceania & $\begin{array}{c}\text { Sub- } \\
\text { Saharan } \\
\text { Africa }\end{array}$ \\
\hline $\begin{array}{l}\text { Bulgaria } \\
\text { Croatia } \\
\text { Cyprus } \\
\text { Czech } \\
\text { Republic } \\
\text { Estonia } \\
\text { Hungary } \\
\text { Latvia } \\
\text { Lithuania } \\
\text { Macedonia } \\
\text { Malta } \\
\text { Moldova } \\
\text { Poland } \\
\text { Romania } \\
\text { Russia } \\
\text { Slovak } \\
\text { Republic } \\
\text { Slovenia } \\
\text { Turkey } \\
\text { Ukraine }\end{array}$ & $\begin{array}{l}\text { Bangladesh } \\
\text { Cambodia } \\
\text { China } \\
\text { Georgia } \\
\text { India } \\
\text { Indonesia } \\
\text { Iran } \\
\text { Japan } \\
\text { Kazakhstan } \\
\text { Korea, Rep. } \\
\text { Kyrgyz } \\
\text { Republic } \\
\text { Malaysia } \\
\text { Mongolia } \\
\text { Nepal } \\
\text { Pakistan } \\
\text { Philippines } \\
\text { Singapore } \\
\text { Sri Lanka } \\
\text { Thailand } \\
\text { Uzbekistan }\end{array}$ & $\begin{array}{l}\text { Austria } \\
\text { Belgium } \\
\text { Denmark } \\
\text { Finland } \\
\text { France } \\
\text { Germany } \\
\text { Greece } \\
\text { Iceland } \\
\text { Ireland } \\
\text { Italy } \\
\text { Luxembourg } \\
\text { Netherlands } \\
\text { Norway } \\
\text { Portugal } \\
\text { Spain } \\
\text { Sweden } \\
\text { Switzerland } \\
\text { United } \\
\text { Kingdom }\end{array}$ & $\begin{array}{l}\text { Argentina } \\
\text { Bolivia } \\
\text { Brazil } \\
\text { Chile } \\
\text { Colombia } \\
\text { Costa Rica } \\
\text { Dominican } \\
\text { Republic } \\
\text { Ecuador } \\
\text { Guatemala } \\
\text { Honduras } \\
\text { Jamaica } \\
\text { Mexico } \\
\text { Nicaragua } \\
\text { Panama } \\
\text { Paraguay } \\
\text { Peru } \\
\text { Trinidad } \\
\text { and } \\
\text { Tobago } \\
\text { Uruguay } \\
\text { Venezuela }\end{array}$ & $\begin{array}{l}\text { Afghanistan } \\
\text { Algeria } \\
\text { Bahrain } \\
\text { Egypt } \\
\text { Israel } \\
\text { Jordan } \\
\text { Kuwait } \\
\text { Morocco } \\
\text { Saudi } \\
\text { Arabia } \\
\text { Tunisia } \\
\text { United } \\
\text { Arab } \\
\text { Emirates } \\
\text { Yemen }\end{array}$ & $\begin{array}{l}\text { Canada } \\
\text { United } \\
\text { States }\end{array}$ & $\begin{array}{l}\text { Australia } \\
\text { New } \\
\text { Zealand }\end{array}$ & $\begin{array}{l}\text { Angola } \\
\text { Benin } \\
\text { Botswana } \\
\text { Burkina } \\
\text { Faso } \\
\text { Cameroon } \\
\text { Chad } \\
\text { Ethiopia } \\
\text { Gambia } \\
\text { Ghana } \\
\text { Kenya } \\
\text { Lesotho } \\
\text { Madagascar } \\
\text { Malawi } \\
\text { Mali } \\
\text { Mauritania } \\
\text { Mauritius } \\
\text { Namibia } \\
\text { Nigeria } \\
\text { South } \\
\text { Africa } \\
\text { Tanzania } \\
\text { Uganda } \\
\text { Zambia } \\
\text { Zimbabwe }\end{array}$ \\
\hline
\end{tabular}




\section{Section 5. County-level Data for France in the $19^{\text {th }}$ Century}

The data used in this paper are mainly extracted from books published by the Statistique Générale de la France (SGF) on population, demographic and public education censuses, between 1800 and 1925 (1821, 1851, 1861, 1867, 1881, 1911 Censuses). Almost all data are available for 86 counties.

\section{Census}

- Crude birth rate. Number of birth over total population (per 1000 inhabitants).

- School enrollment rate. Number of children enrolled in public primary schools over the total number of children aged 6-14.

- Girls (Boys) enrollment rate. Number of girls (boys) enrolled in public primary schools over the total number of girls (boys) aged 6-14.

- Share in industry. Number of individuals employed in manufacturing over total population. Manufacturing refers to all types of industry: textile, metal sector and other factories (food, wood, construction...).

- Female (Male) in industry. Number of women (men) employed in manufacturing over total number of women (men) aged 15-60. Manufacturing refers to all types of industry: textile, metal sector and other factories (food, wood, construction...).

- Share in agriculture. Number of individuals employed in agriculture over total population. Agriculture refers to all positions within agricultural sector: owners, farmers, sharecroppers and others.

- Female (Male) in agriculture. Number of women (men) employed in agriculture over total number of women (men) aged 15-60. Agriculture refers to all positions within agricultural sector: owners, farmers, sharecroppers and others.

- Urbanization. Number of towns populated with more than 2000 inhabitant (per $\mathrm{km}^{2}$ ).

- Population density. Number of people per $\mathrm{km}^{2}$.

- Life expectancy at age 0. Updated C7 tables published in Bonneuil (1997). Calculation of life expectancy by calculating the area under the survival function. 
- Marital fertility rate. Index of marital fertility from Princeton European Fertility Project. $I_{g}$ index compares the observed number of marital births to the number of marital births expected if the standard fertility rates applied.

- Share married women. Number of married women per women in age of being married (15 years old and above). Number of married women refers to the sum of married women at each age (from 15 years to 100 years and above).

\section{Census}

- Share Protestants. Number of Protestants over total people within the different religions (per hundred people). Protestants refers to all types of Protestants: Lutherans, Calvinists and other Protestant sects. Religions refer to all types of Protestants, Catholics, Israelite and other non-Christian cults.

- Female (Male) workers. Number of female (male) workers in textile industries over total female (male) population.

1881 Census

- Crude birth rate. Number of birth over total population.

\section{Percentage Changes}

- Crude birth rate (1881-1911) - \% change. Percentage variation of the number of birth over total population in 1881 compared to 1911.

- Marital fertility rate (1881-1911) - \% change. Percentage variation of index of marital fertility in 1881 compared to 1911, from Princeton European fertility project

- Girls (boys) enrollment rate (1851-67) - \% change. Percentage variation of the girls (boys) enrollment rate between 1851 and 1867.

- Female (Male) literacy rate (1856-66) - \% change. Percentage variation of the female (male) literacy rate between 1856 and 1866. The literacy rate consists in number of individuals able to read and to write over total population. 